\title{
Defining fault avoidance zones and associated geotechnical properties using MASW: a case study on the Springfield Fault, New Zealand
}

\author{
Brendan Duffy ${ }^{\mathrm{a}, *}$, Jocelyn Campbell $^{\mathrm{a}}$, Michael Finnemore ${ }^{\mathrm{a}, \mathrm{b}}$, Christopher Gomez $^{\mathrm{c}}$ \\ a Department of Geological Sciences, University of Canterbury, Private Bag 4800, Christchurch 8140, New Zealand \\ b Southern Geophysical Limited, 3/28 Tanya Street, Bromley, Christchurch 8062, New Zealand \\ c Department of Geography, University of Canterbury, Private Bag 4800, Christchurch 8140, New Zealand
}

\section{A R T I C L E I N F O}

\section{Article history:}

Received 19 November 2013

Received in revised form 15 October 2014

Accepted 20 October 2014

Available online 28 October 2014

\section{Keywords:}

MASW

Neotectonics

Tectonic geomorphology

Shear waves

New Zealand

Fault-zone planning

\begin{abstract}
A B S T R A C T
The Springfield thrust fault at Dalethorpe, west Canterbury, New Zealand, provides a test case to explore the correlation between shear wave velocities at a range of scales, and direct field observations of distributed deformation and outcrop properties. The Springfield fault ruptures to the surface through hard Torlesse greywacke, overlain on a flight of late Quaternary glacio-fluvial terraces by $\sim 5 \mathrm{~m}$ of gravel. Fault slip has displaced all but the lowest terraces, revealing the geometry and location of faulting. We used multi-channel analysis of surface waves and meter-scale cross-hole measurements to map shear wave velocities below the lowest, apparently undisplaced, terrace. We correlated these surveys with geotechnical parameters measured at outcrops and investigated relationships in the laboratory. Both field and laboratory results indicate that the shear wave velocity of Torlesse greywacke declines sharply with increasing fracture density. Field surveys further indicate that relatively unweathered, high velocity greywacke is being exhumed in a bivergent wedge between two oppositefacing thrusts. The fracturing and low shear wave velocities are focused in a wide, low-velocity damage zone that has developed in the hanging wall of the main thrust, and a smaller but similar feature in the hanging wall of the backthrust. This is consistent with the geomorphology of the site. Our correlations of geomorphic indicators of deformation with fault zone velocity structure provide a useful method with which to characterize the distribution of cumulative strain. This type of analysis has utility for land use planning on, or close to, active faults, especially where they are obscured by fluvial deposits.
\end{abstract}

(C) 2014 Elsevier B.V. All rights reserved.

\section{Introduction}

Land use planning within active tectonic settings is needed to ensure that capital investment projects survive safely throughout their design life. Development in mountainous areas commonly occurs within small alluviated catchments where it may be challenging to define the location and width of partly or completely hidden fault zones. The challenge is increased because the internal structure of faults is not limited to a simple planar surface but incorporates a damage zone ranging up to hundreds of metres in extent, within which complex distributed deformation may take place. For example, well documented observations from surface rupturing earthquakes such as Algeria (King and Vita-finzi, 1981; Yielding et al., 1981; Ruegg et al., 1982; Philip and Meghraoui, 1983), Chi Chi (Kelson et al., 2001; Lee et al., 2006, 2010, 2011) and recently New Zealand (Van Dissen et al., 2011; Quigley et al., 2012; Duffy et al., 2013), demonstrate that folding, tilting and secondary faulting in a variety of configurations may extend well beyond the main rupture trace.

\footnotetext{
* Corresponding author.

E-mail address: brendan.duffy@canterbury.ac.nz (B. Duffy).
}

Buildings sited across discrete surface ruptures invariably sustain the greatest rupture-related damage during an earthquake, followed by those buildings that lie within the zone of distributed deformation, in close proximity to the fault (Kelson et al., 2001; Van Dissen et al., 2011). New Zealand's guidelines for development adjacent to active faults therefore specify fault-avoidance zones that are scaled based on whether deformation is discrete or distributed (Kerr et al., 2003; Villamor et al., 2012). However, in cases where the fault trace is degraded or buried by inter-seismic sedimentation, it can be difficult to map its complexities (e.g. Hart and Bryant, 1997; Similox-Tohon et al., 2006) and therefore difficult to establish a deformation setback. This leads to uncertainties that contribute to uneconomic decisions, and complicate local authority implementation of planning guidelines (e.g. Becker et al., 2005).

Competent rock masses that are cut by faults commonly develop wide zones within which the rocks are intensely fractured and pulverised to micron-scale (Dor et al., 2006a,b; Rempe et al., 2013). This rock mass fracturing is commonly associated with zones of distributed deformation (e.g. King and Nábělek, 1985). Characterization of the within-zone spatial variability in lithology, fracturing, fabric development and cataclasis is therefore a potential way to understand past and likely future distribution of deformation. Furthermore, ground 
motion polarization that is commonly observed in fault zones is interpreted as fracture-controlled (e.g. Pischiutta et al., 2012; Panzera et al., 2014). These studies show that the frequency bands at which directional amplification occurs reflects asymmetry in rock damage. For this reason, studies of shear wave velocity and directional site effects are important to mitigate the damaging effects of strong ground motion on infrastructure.

Fracturing and cataclasis reduce shear wave velocities (e.g. Zinszner et al., 2002; Gettemy et al., 2004; Rempe et al., 2013), which control the dispersion and velocity of Rayleigh waves (Xia et al., 1999). The dispersion and velocity of Rayleigh waves are used in surface wave surveys to determine changes in shear wave velocities with depth (Stokoe et al., 1994; Park et al., 1999). The multi-channel analysis of surface waves (MASW) technique (Park et al., 1999), which we use here, assumes that the subsurface conforms to a laterally homogeneous layered earth model in which the average velocity can be assigned to the middle of the receiver spread (Luo et al., 2009). However, MASW can and has been successfully used to characterize large lateral shear wave velocity changes in the near surface (Miller et al., 1999; Ivanov et al., 2006; Luo et al., 2009).

Shear wave velocity surveys are already an important part of site investigations in tectonically active areas. Strong ground motion (Borcherdt and Glassmoyer, 1992; Anderson et al., 1996; Dobry et al., 2000) and liquefaction (Andrus and Stokoe, 2000; Lin et al., 2004; Yunmin et al., 2005; Zhang, 2010) are both commonly considered to be a function of shear wave velocity in the upper $30 \mathrm{~m}$. Steep, narrow ridges (Buech et al., 2010; Hough et al., 2010) and landslide deposits (Burjánek et al., 2012) commonly experience topographic amplification. Aside from geometry, and fracture orientation relative to the ridgeline, shear wave velocity is the major predictor of topographic amplification in these situations.

The relationship between deformation, cataclasis, shear wave velocities and surface wave velocities suggests that mapping the spatial variability in subsurface shear wave velocities with MASW as part of a wider site investigation process might be expected to provide an economically attractive insight into past and future distribution of deformation on a buried fault zone. In addition to large scale surveys, site investigations commonly include laboratory-scale analysis. It is well known that material heterogeneity across a fault-zone may induce apparent dispersion (frequency-dependent velocity) between laboratory and field analyses (e.g. Mukerji et al., 1995; Gettemy et al., 2004). This occurs due to the significant lithological, geotechnical, fluid and stress variations that occur at scale lengths from $<5 \mathrm{~mm}$ to $>5 \mathrm{~m}$ and interact differently with different wavelengths. In this study, we therefore conduct seismic studies at several scales ranging from ultrasonic laboratory testing to crosshole and seismic surveys that average sonic velocities over metres to tens of metres. We focus on objectives that will provide a clear planning advantage by not only identifying the projected position of the principle slip surface, but also by elucidating the relationships of shear wave velocities to the width of the zone of damaged rock, and the distribution of off-plane deformation.

On the 4th September 2010, a major earthquake series began in the Canterbury region of the South Island of New Zealand (Figure 1), beginning with surface rupture on the Greendale fault (Quigley et al., 2010, 2012; Van Dissen et al., 2011) (Figure 2). The surface rupture provided an example for retrospective application of the New Zealand approach to fault zone planning (Villamor et al., 2012). However, careful fault zone planning is more critical along active faults that have not recently ruptured. One such fault is the Springfield fault at Dalethorpe (SFD), which lies in a zone of increased shear stress following the Canterbury earthquake sequence (Steacy et al., 2014). The SFD forms an upstream-facing fault scarp that displaces a flight of glaciofluvial terraces in the Upper Hawkins River catchment, about $70 \mathrm{~km}$ west of Christchurch (Figure 3). The SFD is generally well defined but is obscured for a short distance under the gravels overlying the lowest terrace (terrace Ta in Figure 3). Sheared bedrock is exposed in an outcrop

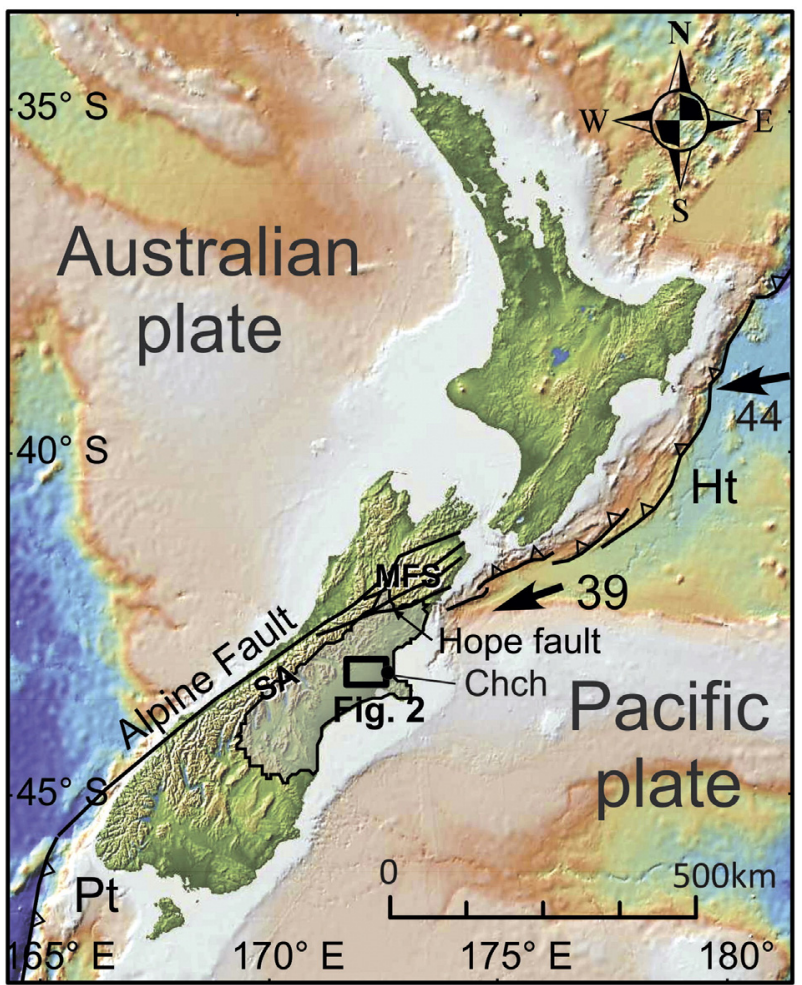

Fig. 1. Tectonic setting of New Zealand, showing elements of the New Zealand plate boundary and relative motion vectors $(\mathrm{mm} / \mathrm{yr}$ ) between the Australian and Pacific plates (DeMets et al., 2010). Shaded relief topography and bathymetry from GeomapApp. Chch Christchurch; SA - Southern Alps; MFS - Marlborough fault system; Ht - Hikurangi trench; Pt - Puysegur trench; The shaded area surrounding the rectangle is the province of Canterbury.

in the terrace edge below terrace Ta (Figure 4). In this study we define the velocity structure of the SFD below the lowest terrace using multichannel analysis of surface waves (MASW) surveys run on the lowest terrace, outcrop scale shear wave and geotechnical surveys in the exposed river outcrops that transect the hanging wall of the fault zone, and laboratory analyses. We correlate our seismic and geological observations with the geomorphic distribution of cumulative ground deformation that has offset the upper, older terraces (terraces $\mathrm{Tb}$ and $\mathrm{Tc}$ in Figure 3). On this basis we document the likely distribution of ground deformation across the fault. We suggest that MASW surveys provide a reliable option to define fault-avoidance zones for buried faults developed in Torlesse Supergroup basement rocks in New Zealand, and are likely to correlate with analogous properties of shear zones in most indurated lithologies.

\section{Tectonic setting, geology and seismic properties of the study area}

New Zealand occupies the boundary between the Pacific and Australian plates, at a location where they converge obliquely at rates of 30-50 mm yr (DeMets et al., 2010) (Figure 1). Opposite sense subduction at the Hikurangi and Puysegur trenches (north and south of the New Zealand respectively) is transferred through the strike-slip Marlborough fault system and the resulting convergence drives uplift of the Southern Alps along the Alpine fault (Norris and Cooper, 2001) (Figure 1). Eastward expansion of the Southern Alps (Campbell et al., 2012) and southward migration of the Marlborough fault system (Cowan et al., 1996; Little and Jones, 1998) gives rise to a zone of hybrid thrusting and strike-slip on the Canterbury rangefront, including the SFD (Pettinga et al., 2001; Campbell et al., 2012).

Shortening and uplift has exhumed the Mesozoic Torlesse greywacke metasedimentary basement (Andrews et al., 1976) across much of Canterbury, including the study area. The Torlesse Supergroup 


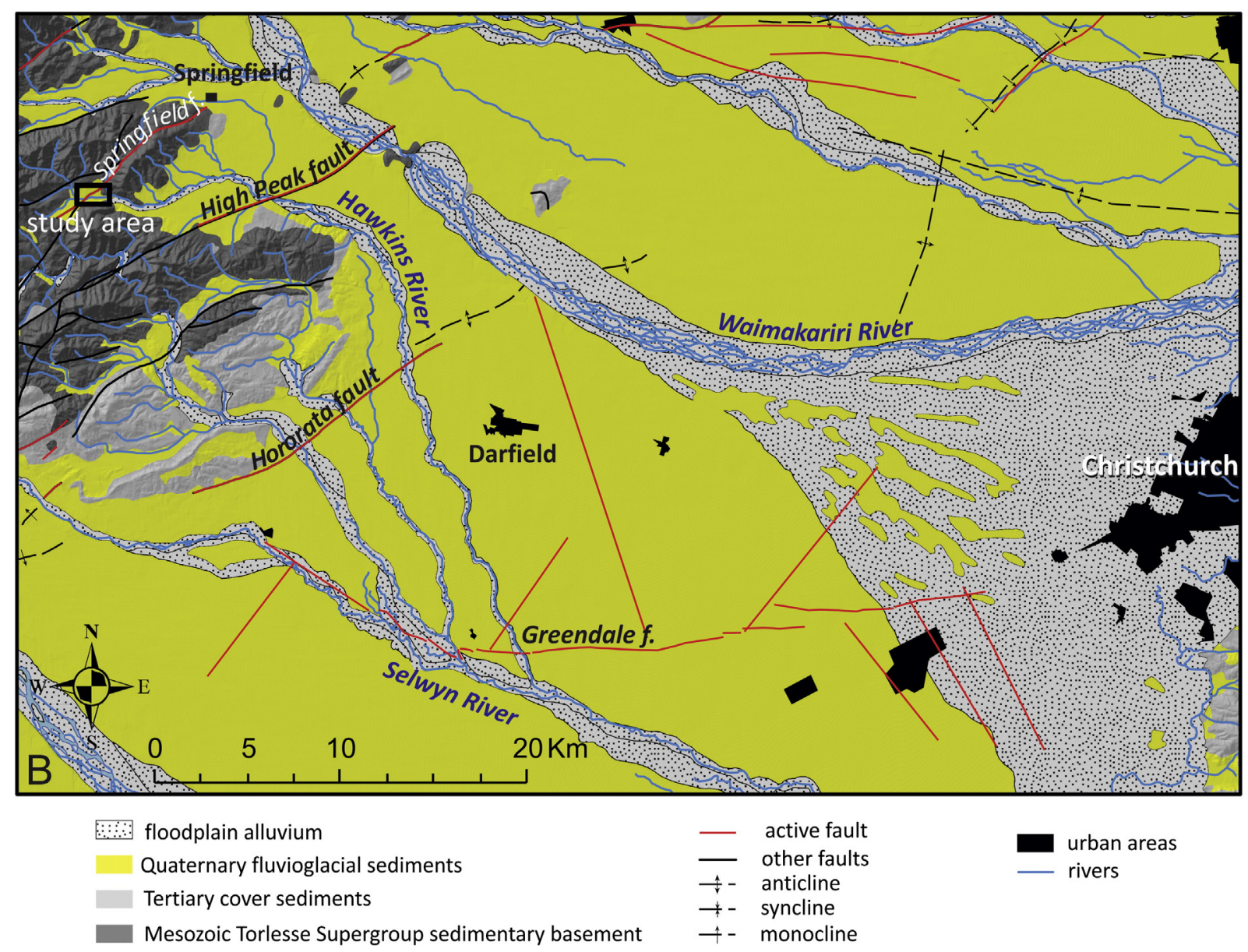

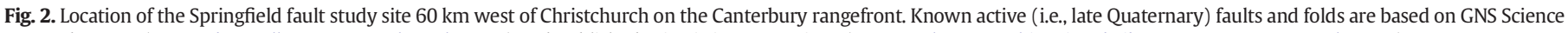
QMAP data sets (Cox and Barrell, 2007; Forsyth et al., 2008) and published seismic interpretations (Dorn et al., 2010; Ghisetti and Sibson, 2012; Jongens et al., 2012).

is generally a massive, steeply-dipping, well graded/poorly sorted, hard to very hard turbidite sequence of thickly bedded, quartzofeldspathic, medium sandstones interbedded with thin ( $<1 \mathrm{~m}$ thick), and hard argillite beds. In general, these greywackes are closely-jointed and often slightly metamorphosed (Read et al., 1999). The intact rock material is strong to very strong, and unconfined compressive strengths range from 60 to $350 \mathrm{MPa}$, although rock mass GSI rarely exceeds 60 and is commonly $<5$ in zones of major faulting (Richards et al., 2001). Stahl et al.'s (2013) schmidt hammer testing of Torlesse greywacke clasts indicates that fresh greywacke is relatively homogeneous in strength characteristics across the South Island of New Zealand.

In the near surface, shear wave velocities in the Torlesse greywacke show distinctive gradients related to depth and weathering (e.g. Hicks, 2011). Highly to moderately weathered greywackes have low velocity gradients, ranging upward of $500 \mathrm{~m} / \mathrm{s}$ and rarely exceeding $800 \mathrm{~m} / \mathrm{s}$ in the top $20 \mathrm{~m}$. Slightly weathered to fresh greywackes display steep velocity gradients with increasing depth, and velocities commonly exceed $1500 \mathrm{~m} / \mathrm{s}$. Similarly, shear wave velocities for Torlesse greywacke derived from seismic refraction experiments range from 365 to $1760 \mathrm{~m} / \mathrm{s}$ (completely to unweathered rock respectively - Semmens et al., 2010). An average shear wave velocity of $1500 \mathrm{~m} / \mathrm{s}$ is commonly used to represent greywacke in the upper $1 \mathrm{~km}$ of the crust (e.g. Benites and Olsen, 2005; Buech et al., 2010). Ultrasonic shear wave velocities at simulated upper crustal confining pressures range up to $3250 \mathrm{~m} / \mathrm{s}$ (Okaya et al., 1995), which is the typical value quoted for shear wave velocities at depths $>1 \mathrm{~km}$ (Okaya et al., 1995; Benites and Olsen, 2005).

\section{The Springfield fault at Dalethorpe}

The SFD is a southeast-dipping thrust fault located $60 \mathrm{~km}$ west of Christchurch on the Canterbury range-front (Figure 2). The fault displaces alluvial surfaces preserved in the Upper Hawkins catchment (Speight, 1928; Evans, 2000; Duffy, 2008) (Figure 3). The greywacke of the Upper Hawkins catchment is locally overlain by outliers of unconformable cover sequence on the footwall side of the SFD (Speight, 1928) (Cross-section AA', Figure 3). The SFD uplifts the greywacke on the Russell Range, displacing the unconformity by $>100 \mathrm{~m}$ within the limited area covered in this study (Evans, 2000). Bedding strikes approximately north-northeast, subparallel to the strike of the SFD. The SFD is clearly exposed in an outcrop in the Hawkins River, where the fault-zone comprises multiple steeply-dipping foliated shear zones in greywacke that is thrust over gravel (Figure 4).

Two branches of the Hawkins River, referred to hereafter as the S. Hawkins River and the N. Hawkins River, drain the Upper Hawkins catchment (Figure 3). The S. Hawkins River and minor tributaries feed into the catchment from the west and northwest, and hug its western and southern sides. The N. Hawkins River flows southward into the catchment along its eastern boundary. Only minor drainage is found in the central catchment. Both branches of the Hawkins River pass across the fault zone, exiting the catchment through a gap in its southeast corner, and eventually joining the local baselevel of the Selwyn River. In the catchment close to the SFD, the S. Hawkins River develops a series of northeast trending reaches that are separated by eastward flowing reaches. 


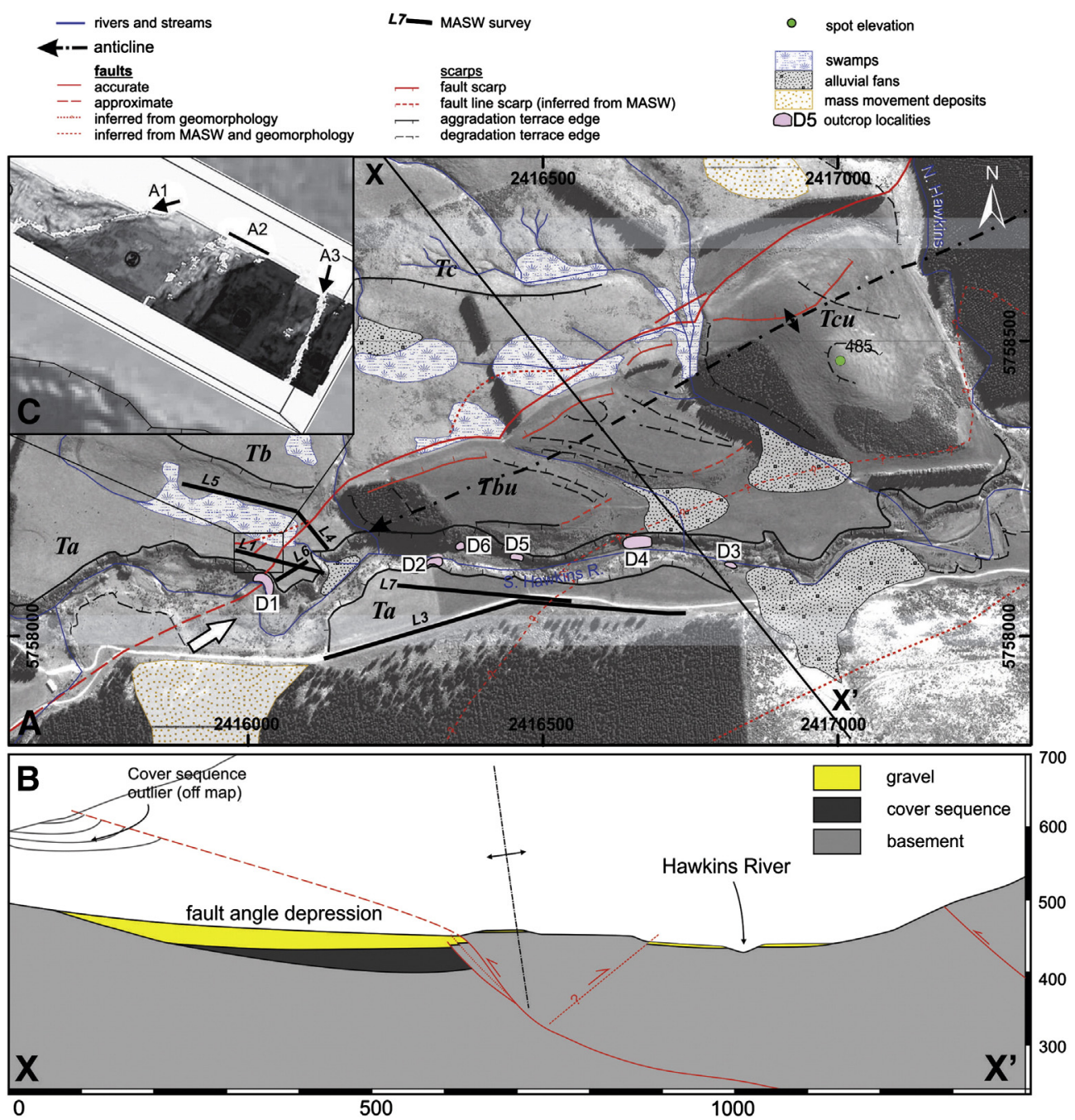

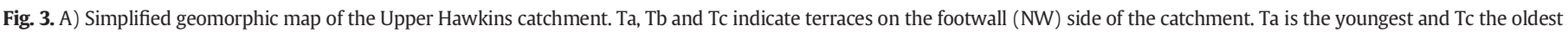

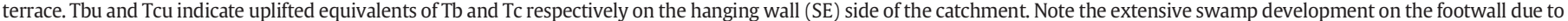

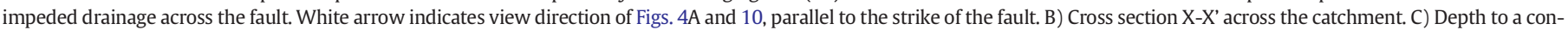

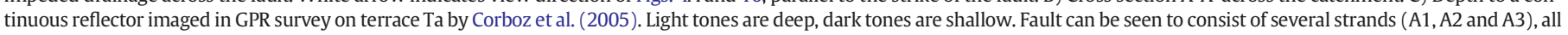
upthrown to the southeast.

Perched above the Hawkins River, Late Quaternary glacio-fluvial terraces occupy the majority of the central catchment (Figure 3 ). These terraces comprise variable thicknesses of gravels overlying bedrock strath surfaces. Where the fault intersects with these terraces, it forms a fault scarp that increases in elevation as it offsets successively older terraces. The lowest, youngest terrace (Terrace Ta) does not have an obvious scarp, although a swamp attests to ponded drainage on the terrace tread (Figure 3). GPR and resistivity tomography indicate three discrete shear zones in the apparently-undisturbed gravels (Corboz et al., 2005) (see inset Figure 3A). Of these, shear zones A2 and A3 project through the exposure of sheared greywacke in the adjacent river bank at outcrop D1.

\section{Material and methods}

\subsection{Outcrop-scale measurements}

The rock mass at several localities in the S. Hawkins River was characterized using scanline fracture counts (pulverized rock) and defect spacing and orientation (other rock masses). We also estimated the geological strength index (GSI) (Hoek et al., 1998) as modified for cataclastic rocks (Habimana et al., 2002). Within the pulverised rock mass at outcrop D1 (Figure 4), we drilled thirteen $32 \mathrm{~mm}$ diameter, sub-horizontal holes, up to $0.7 \mathrm{~m}$ deep, for crosshole shear wave velocity measurements. The holes were located so as to sample as closely as possible fault-zone elements that were internally geotechnically homogenous. The holes were lined with $1 \mathrm{~m}$ long, $32 \mathrm{~mm}$ diameter pvc pipes. The trend and plunge of the pipes were recorded, along with a theodolite survey of the outer end of the pipe, so that the sourcereceiver separation could be calculated. Distances ranged from 0.7 to $2.64 \mathrm{~m}$. A series of cross-hole shear wave velocity measurements were made using a slide-hammer and geophone (Figure 5). Each measurement was recorded as a text file. The signal voltage was graphed as a function of time. Shear wave arrival times were picked where voltage increased abruptly from background, and crosshole velocities were computed using the arrival time and calculated source-receiver distance.

\subsection{Laboratory testing}

Laboratory experiments were designed to investigate the effect of controlled fracturing on shear wave velocity for otherwise intact specimens and to relate the shear wave velocity to the physical properties of pulverized rock specimens. 

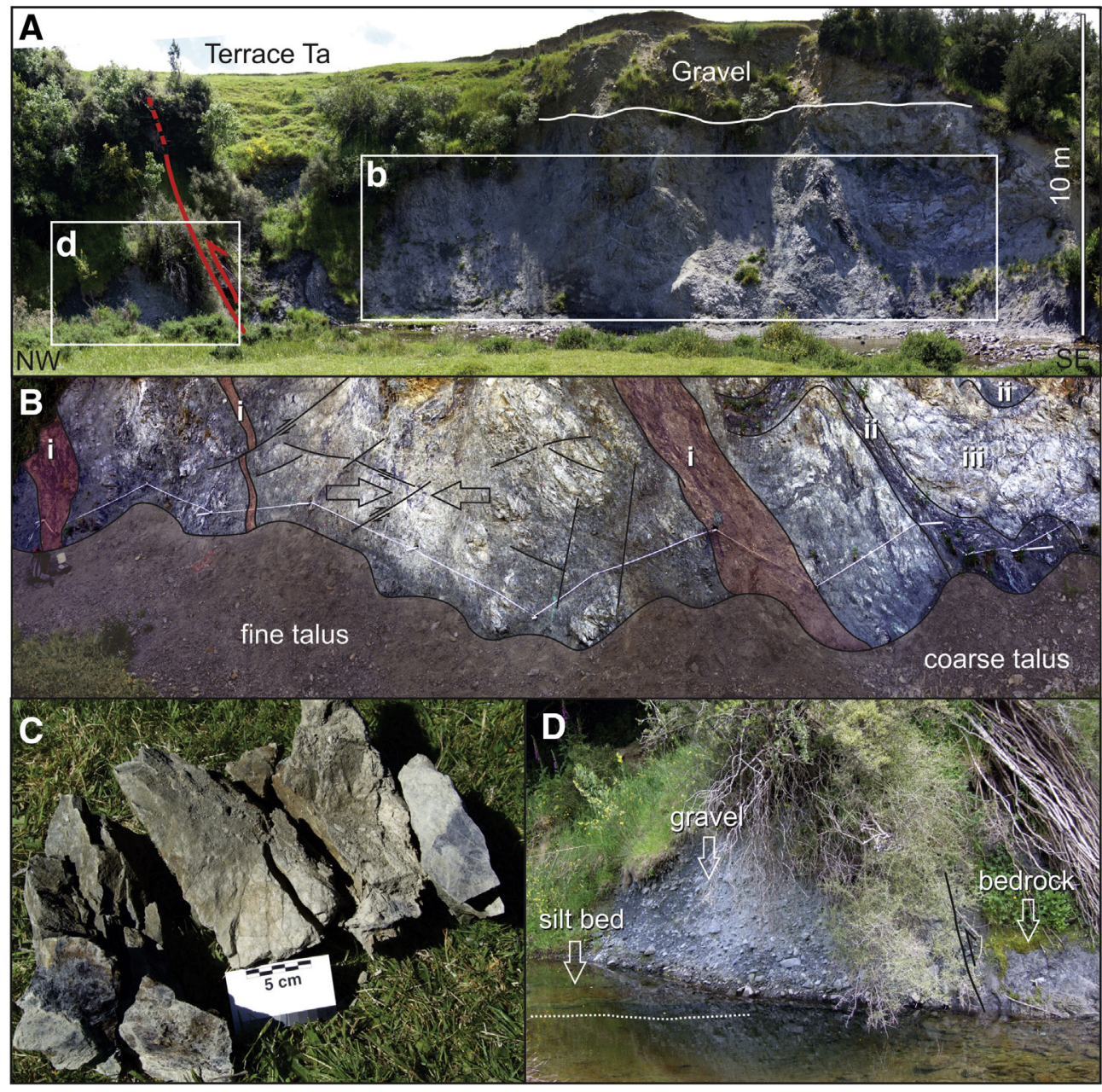

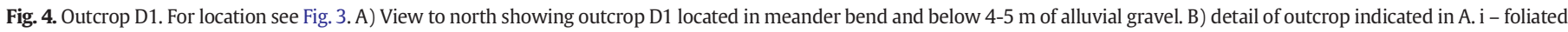

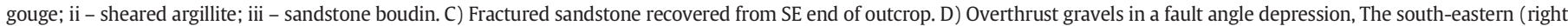
hand) end of the photo shows sheared greywacke, while most of the visible outcrop in this photo consists of gravels with a single silt bed visible just below the water line.

\subsubsection{Intact rock}

Due to the lack of in-situ samples of intact rock we report intact rock results from a loose greywacke boulder ( $400 \mathrm{~mm}$ diameter) collected in the bed of the S. Hawkins River close to outcrop D1. The sample originates from within the Hawkins River catchment. $50 \mathrm{~mm}$ diameter cylindrical core specimens were taken from the boulder, sampling in three mutually perpendicular directions. Physical properties including unconfined compressive strength (UCS), density and porosity, were determined for the intact boulder. UCS was determined for any cores not required for the fracturing experiment, and for remnant core from that experiment, following the ISRM guidelines (ISRM, 1979). Remnant cores, or short cores created by breaking of core along pre-existing fractures, were tested if their length to diameter ratio exceeded 1 . The measured UCS was corrected using the relationship proposed by Turk and Dearman (1986), which keeps results within $\pm 5 \%$ of values obtained using cores with L:D of 2:1.

The axial shear wave velocities of the intact cores were measured using the GCTS Testing Systems ULT-100 ultrasonic velocity measurement system. The individual cores were then incrementally 'fractured' by sawing discs off the end of the core at regular intervals. The cuts were normal to the core axis and shear wave velocity was measured after each cut. Corrections made for length lost from the saw cut thickness. The thicknesses of the sawn discs were recorded, along with average fracture spacing (metres/fracture) or linear fracture density (fractures/metre). Fractured core ultrasonic velocities were all measured at a nominal axial compressive stress determined from the initial testing to be the minimum required for effective coupling. Fractures were progressively introduced until shear waves were completely attenuated.

\subsubsection{Tectonized rock}

Density, porosity, point load strength and ultrasonic velocity were determined for selected samples taken from pulverized (outcrop D1) and more lightly tectonized outcrops (outcrop D2). All of these samples were too internally fractured to yield any suitable core. In consequence, we sawed irregular, roughly rectangular blocks that were limited in size by disaggregation of the sample along pre-existing fractures. Methods for determining the properties of these blocks are summarized in Table 1 . We note that factors such as slightly non-parallel faces and incomplete fit of the transducer on the contact face may contribute to systematic errors in the seismic velocity data.

\subsection{MASW surveys}

We used multi-channel analysis of surface waves (MASW) (Park et al., 1999) to derive 2D shear wave velocity profiles by inversion of fundamental mode Rayleigh wave dispersion.

\subsubsection{Data acquisition}

Multichannel shot records were collected in a roll-along type survey using a linear string of twenty four $8 \mathrm{~Hz}$ geophones (Figure 6). The geophones were mounted on $\sim 1 \mathrm{~kg}$ steel ground-contact sleds connected 


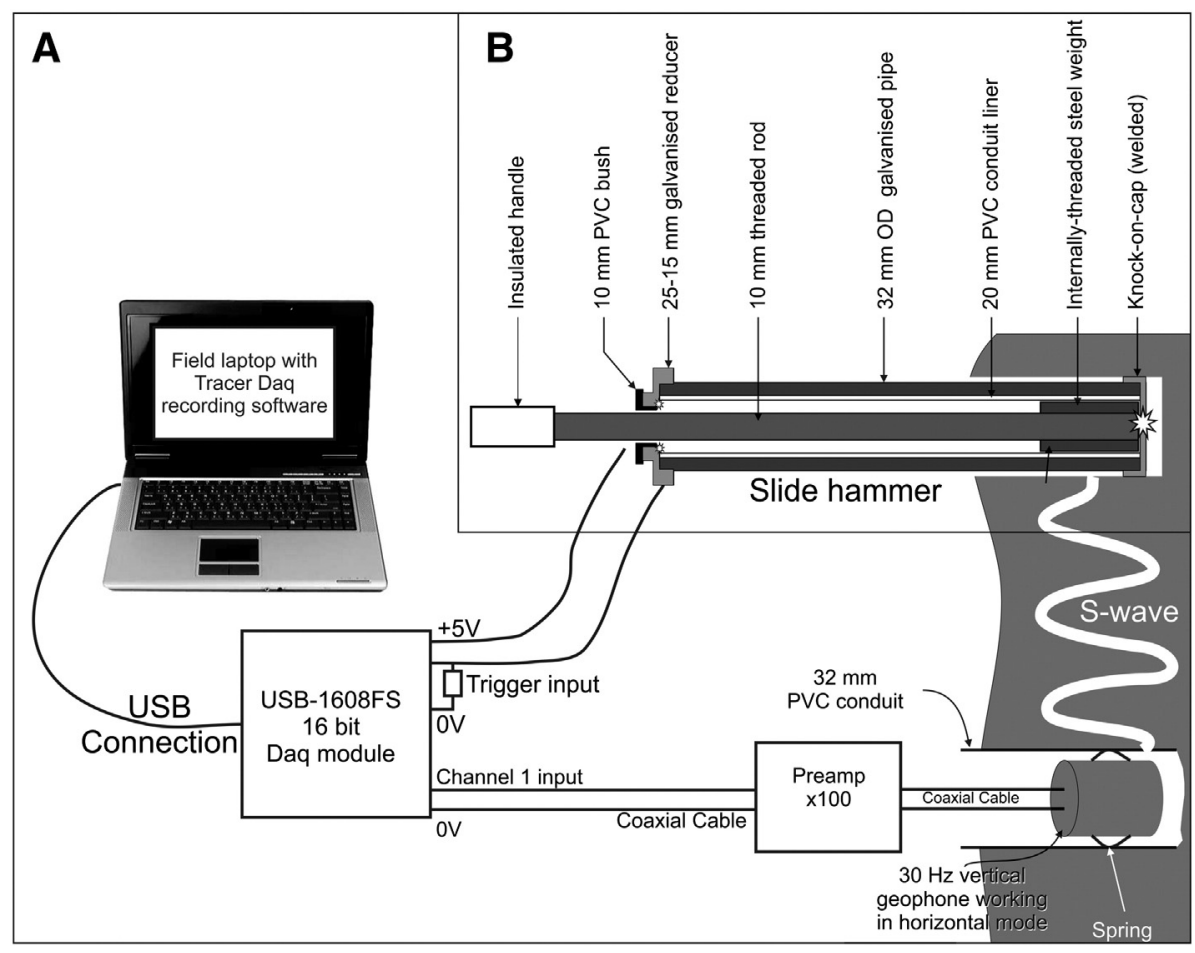

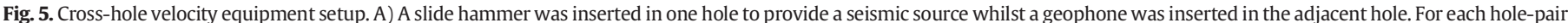

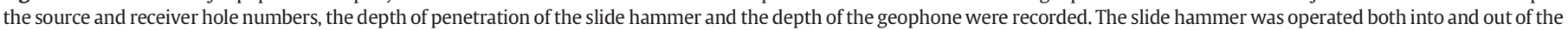

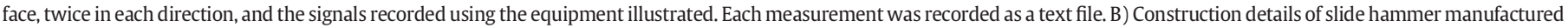

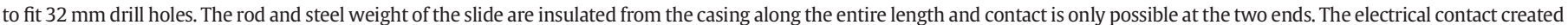

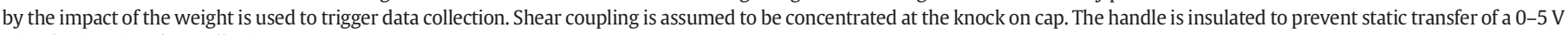
'signal' triggering data collection.

together in a land-streamer. The position of the centre of the string was recorded relative to local survey pegs by a total station survey. The tow vehicle was rolled back slightly and switched off between shots to avoid transmission of noise from the vehicle to the geophone string. Aside from the vehicle, cultural noise during all surveys was limited to distant livestock movement, whilst the main environmental noise source was wind, gusting up to $55 \mathrm{~km} / \mathrm{h}$. Survey geometry was selected to optimize recording of ground roll signals. An $8 \mathrm{~kg}$ sledgehammer with an accelerometer on the hammer handle was used to provide an impulse source and trigger data collection. Shots were recorded using 24 channels of a Geometrics Strataview 48 channel seismograph. No filters were used and eight shots were stacked at each location to reduce the ambient

Table 1

Calculation of properties for irregular block samples, following ISRM (1985).

\begin{tabular}{ll}
\hline Property & Calculation \\
\hline Bulk volume $\boldsymbol{V}\left(\mathrm{m}^{3}\right)$ & $V=\frac{M_{s}-M_{s s}}{\rho_{w}}$ \\
Porosity $n(\%)$ (pore volume expressed as a percentage of total & $n=\frac{M_{s}-M_{d}}{\rho_{w} \times V} \times 100$ \\
volume) & $D e^{2}=\frac{4 A}{\pi}$ \\
Effective sample diameter $D e^{2}$ a & $I s=\frac{P}{D e}$ \\
Point load strength $(I s)^{\text {b }}$ & $I s_{50}=I s \times\left(\frac{D e}{50}\right)^{0.45}$ \\
Size-corrected point load strength index $\left(I s_{50}\right)^{\mathrm{c}}$ &
\end{tabular}

Notes

Variables.

$\mathrm{M}_{\mathrm{s}}$ - vacuum-saturated, surface dried mass ( $\mathrm{kg}$ ).

Mss - vacuum-saturated, submerged mass $(\mathrm{kg})$.

$\mathrm{M}_{\mathrm{d}}$ - the oven dried mass ( $\left.\mathrm{kg}\right)$.

$\rho_{\mathrm{w}}$ - density of water $\left(\mathrm{kgm}^{-3}\right)$.

$\mathrm{A}=\mathrm{WD}$ (the minimum cross-sectional area of the plane through the platens).

$\mathrm{P}$ - failure load (Newtons).

a calculated for point load tests on irregular block samples.

b determined only where fracture passed through both loading points, on specimens

cut to conform with ISRM (1985) guidelines on geometry of irregular blocks.

c correcting Is to a $50 \mathrm{~mm}$ core equivalent result. noise. Details of the survey parameters including geometry, recording time and sampling intervals are given in Table 2.

\subsubsection{Pre-processing}

The data were processed within Surfseis 1.5. Records were individually pre-processed as follows: swept frequency analysis to determine frequency ranges over which velocities are coherent and to determine velocities of body wave and higher mode contamination; F-K filtering to remove backscattered, higher mode and/or body wave contamination; offset time domain muting of higher modes where possible (Ivanov et al., 2005), and muting of the first arrival to improve surface wave signal to noise ratio.

\subsubsection{Dispersion curve extraction}

Surfseis calculates dispersion (phase velocity with frequency) by applying a multichannel coherency measure to a decomposed (swept frequency) record in the offset-frequency domain, and produces a map of velocity against frequency (Park et al., 1998). We extracted only fundamental mode dispersion curves, although newer versions of Surfseis allow picking of multiple modes. The fundamental mode surface wave velocities were picked by user-guided automatic picking at $0.5 \mathrm{~Hz}$ point to point intervals over the full fundamental mode range present in the record.

\subsubsection{Surface wave inversion and contouring}

Dispersion curves were batch-inverted to generate a map of S-wave velocity with depth (Xia et al., 1999). The 2D profile consists of interpolated 1D soundings, each located in the middle of the receiver spread. Default initial 10 layer models defined by Xia et al.'s algorithm were used as they generally converged to geologically acceptable models with an acceptable dispersion curve fit, typically 5-15\%. The thickness of each layer varied between surveys based on the depth of investigation and the recorded bandwidth. 


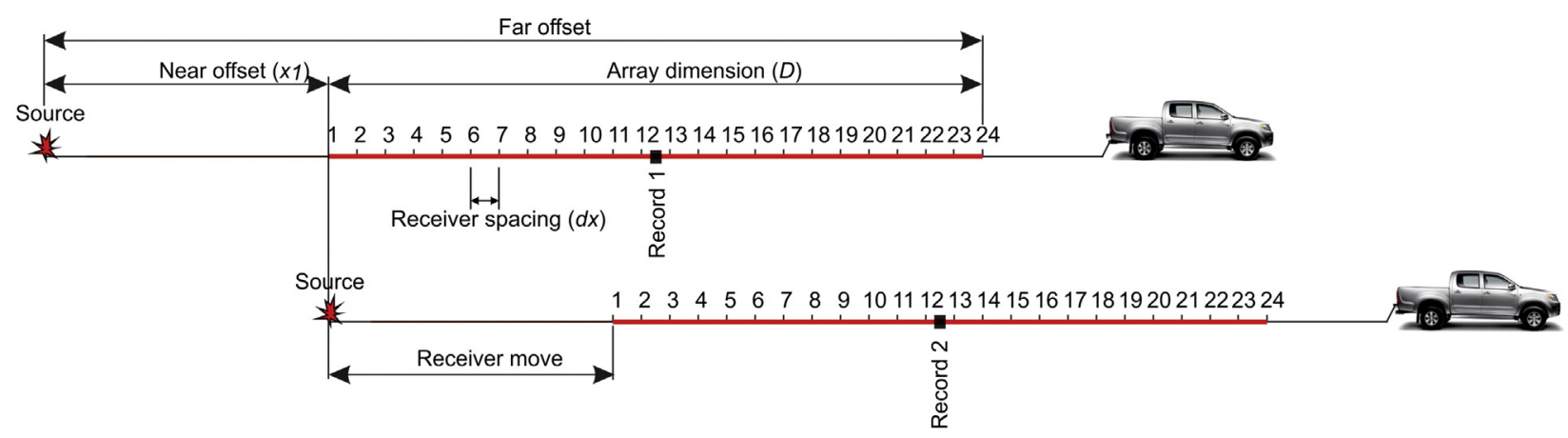

Fig. 6. MASW survey geometry, showing acquisition parameters using a land streamer.

\subsubsection{Survey site selection}

Our MASW surveys targeted the flat surface of Terrace Ta (Figure 3), where the fault zone that displaces the higher terraces is effectively concealed but can be observed in river bank exposures. Survey locations are indicated on Fig. 3.

Survey lines 1 and 2 on this site were collected as part of a pilot project. Line 2 was problematic and is not used here. Line 3 was surveyed along a metalled road, south of the S. Hawkins River and on the hanging wall of the SFD, to identify evidence of folding and/or faulting. Lines 1 and 4 to 6 are located north of the S. Hawkins River on a grassy, sometimes boggy or tussocky, surface underlain by Holocene fluvial gravel. The gravel is mapped as being underlain by Torlesse greywacke bedrock, but Cretaceous coal measures observed in the footwall north of the field area (Speight, 1928) are likely to be present (Figure 3B). Line 4 was located perpendicular to the strike of the fault trace on the terrace above D1. Line 5 provides a continuation of Line 4 westward, parallel with Line 1 and with the S. Hawkins River. Line 6 was collected parallel to the strike of the fault and along the projection of the D1 shear zone, finishing directly above the shear zone outcrop. Line 7 was run subparallel to Line 3 , using a $2 \times 24$ channel fixed source walkaway (Table 2).

\section{Results}

\subsection{Outcrop scale observations}

\subsubsection{Rock mass characteristics}

The SFD is exposed in outcrop D1, where several steeply eastdipping shear zones intersect the outcrop (Figure 4). A shear zone at the west end of the outcrop separates hanging wall greywacke from foot-wall gravel. The exposed shear zones are foliated and clay rich and the central shear zone is the thickest. The sandstone in the footwall of the central shear zone is reduced to $\mathrm{cm}$-scale fragments (Table 3 ) that are defined by closely-spaced, low-angle, fractures. These fractures are intimately associated with conjugate thrust faults that dip both west and east and suggest that the material within this shear-bounded block is being squeezed and vertically extruded (Figure 4B). A few slivers of argillite $(<30 \mathrm{~cm})$ are folded and truncated against the low angle faults.

Table 2

Acquisition parameters for Dalethorpe MASW surveys.

\begin{tabular}{lllllll}
\hline Survey line & 1 & 3 & 4 & 5 & 6 & 7 \\
\hline Channels & 24 & 24 & 24 & 24 & 24 & 48 \\
Near offset (x1) & 10 & $12 \mathrm{~m}$ & 10 & 10 & 10 & $12 \mathrm{~m}$ \\
Geophone spacing (dx) & 1 & $1 \mathrm{~m}$ & $1 \mathrm{~m}$ & $1 \mathrm{~m}$ & $1 \mathrm{~m}$ & $1 \mathrm{~m}$ \\
Shot spacing & 4 & $4 \mathrm{~m}$ & $4 \mathrm{~m}$ & $4 \mathrm{~m}$ & $4 \mathrm{~m}$ & $4 \mathrm{~m}$ \\
Sampling interval (ms) & 0.5 & 0.5 & 0.5 & 0.5 & 0.5 & 1.0 \\
Recording time (ms) & 1000 & 1000 & 1000 & 1000 & 1000 & 1000 \\
\hline
\end{tabular}

Two argillite beds crop out in the hanging wall of the central shear zone (Figure 4B). These beds are folded and sheared but relatively continuous compared with those in the footwall. The intervening sandstones are generally less fractured than those in the footwall, and the presence of large lenses of relatively more intact rock gives rise to a coarser talus on the hanging wall side of the outcrop (Figure 4B). These rocks, which are internally fractured and disaggregate easily (Figure 4C), provided the material suitable for laboratory classification. Overall, outcrop D1, is completely to extremely weathered, often strongly foliated and everywhere intensely fractured. On this basis it is assigned a GSI of $<10$.

The S. Hawkins River exposes Torlesse greywacke in several places along the river's course. We investigated and classified five of these outcrops, designated from D2 through D6 (Figure 3). Outcrop D2 forms the base of a deep gorge in the S. Hawkins River. The outcrop is closely fractured at spacings of $\sim 8.5 \mathrm{~cm}$. At the surface, the fractures are wide $(<1 \mathrm{~cm})$ but the rock material is hard and only moderately weathered. D5 is located close by and has similar characteristics. Both are assigned a GSI value of 50. However, D6 is located between them and exposes a shear zone that is intensely fractured down to $\sim 2 \mathrm{~cm}$ spacings.

Outcrops D3 and D4 lie furthest east in the study area. They are more blocky (14-20 cm fracture spacing) but also more deeply weathered (moderately to completely) than outcrops D2 and D5. These outcrops are assigned a GSI of $\sim 40$.

\subsubsection{Cross-hole velocities of pulverized rocks}

Sonic shear wave velocities measured between horizontal crossholes drilled in the pulverized rock of outcrop D1 vary from 63 to $450 \mathrm{~m} / \mathrm{s}$ (Table 3 and Figure 7). In general, shear wave velocities decline with increasing fracture intensity (Figure 7B\&C). Foliated gouges and sheared argillites returned the lowest velocities $(<200 \mathrm{~m} / \mathrm{s})$. Pulverized sandstones returned generally higher velocities, mostly around $270 \mathrm{~m} / \mathrm{s}$. However, the pulverized rock that bounded the main shear zone returned the highest shear wave velocities of $\sim 450 \mathrm{~m} / \mathrm{s}$.

\subsection{Laboratory results}

\subsubsection{Intact rock}

Table 4 summarizes measurements made during this study of the physical properties of intact and pulverized Torlesse greywacke. The intact boulder cores typically have a porosity of $<0.3 \%$ and a dry mass density of $\sim 2700 \mathrm{~g} / \mathrm{cm} 3$. The shear wave velocities of intact cores range between 2590 and $2950 \mathrm{~m} / \mathrm{s}$ and increase slightly with increasing values of uniaxial stress (Figure $8 \mathrm{~A}$ ). They exhibit a slight 10\% anisotropy in agreement with Okaya et al. (1995), although the data is somewhat scattered at uniaxial stresses $<5 \mathrm{MPa}$ (Figure $8 \mathrm{~A}$ ).

\subsubsection{Artificially fractured rock}

Compared with intact rock, the shear wave velocities of fractured cores are more strongly dependent on the (uniaxial) confining stress 
Table 3

Near-surface physical properties and shear wave velocities at outcrop D1, Dalethorpe.

\begin{tabular}{|c|c|c|c|c|c|c|c|}
\hline & Hole pair & Structural element & Distance (cm) & Number of fractures & Minimum fractures/m (density) & Maximum spacing (mm) & $\mathrm{V}_{\mathrm{s}}(\mathrm{m} / \mathrm{s})$ \\
\hline \multirow[t]{8}{*}{ Footwall } & $1-2$ & Foliated gouge & 58 & $>106$ & 185 & 5.4 & 81 \\
\hline & $2-3$ & Fractured and faulted & 168 & $>186$ & 110 & 9 & 253 \\
\hline & $3-4$ & Fractured and faulted & 205 & $>175$ & 86 & 11.7 & 259 \\
\hline & $4-5$ & Incipient shear zone. & 220 & $>250$ & 114 & 8.8 & 184 \\
\hline & $5-6$ & Fractured and faulted & 265 & $>145$ & 55 & 18.3 & 255 \\
\hline & $6-7$ & Fractured and faulted & 245 & $>130$ & 54 & 18.9 & 255 \\
\hline & $7-8$ & Fractured and faulted & 340 & $>224$ & 65 & 15 & 450 \\
\hline & $8-9$ & Foliated gouge & 190 & $>212$ & 111 & 9 & 174 \\
\hline \multirow[t]{4}{*}{ Hanging wall } & $9-10$ & Massive sandstone & 260 & $>198$ & 76 & 13 & 434 \\
\hline & $10-11$ & Sheared argillite & 105 & $>175$ & 167 & 6 & 157 \\
\hline & $11-12$ & Sheared argillite & 105 & $>180$ & 167 & 6 & 63 \\
\hline & $12-13$ & Sheared argillite and sandstone & 190 & $>160$ & 84 & 12 & 272 \\
\hline
\end{tabular}

at stresses $<18 \mathrm{MPa}$ (Figure 8B), equivalent to $\sim 670 \mathrm{~m}$ of intact overburden. The ultrasonic shear wave velocity of otherwise intact Torlesse greywacke declines systematically as fractures are introduced. Fig. 8B illustrates the effects of introducing approximately equi-spaced fractures into a single core specimen. At a given uniaxial stress $<18 \mathrm{MPa}$, the velocity declines with increased fracturing. A repeat of the experiment with 8 fractures failed because low shear wave velocities failed to recover, probably due to the introduction of microcracks located in the grain contact areas during the preceding test cycles (e.g. Wulff et al., 2000). These microcracks then dominated the shear wave velocity. Subsequent testing utilized only minimal uniaxial stresses of $\sim 5 \mathrm{MPa}$ to achieve coupling but avoid cracking specimens. This also facilitated comparison of core results with rectangular block results, as tectonized block samples could only support small loads.
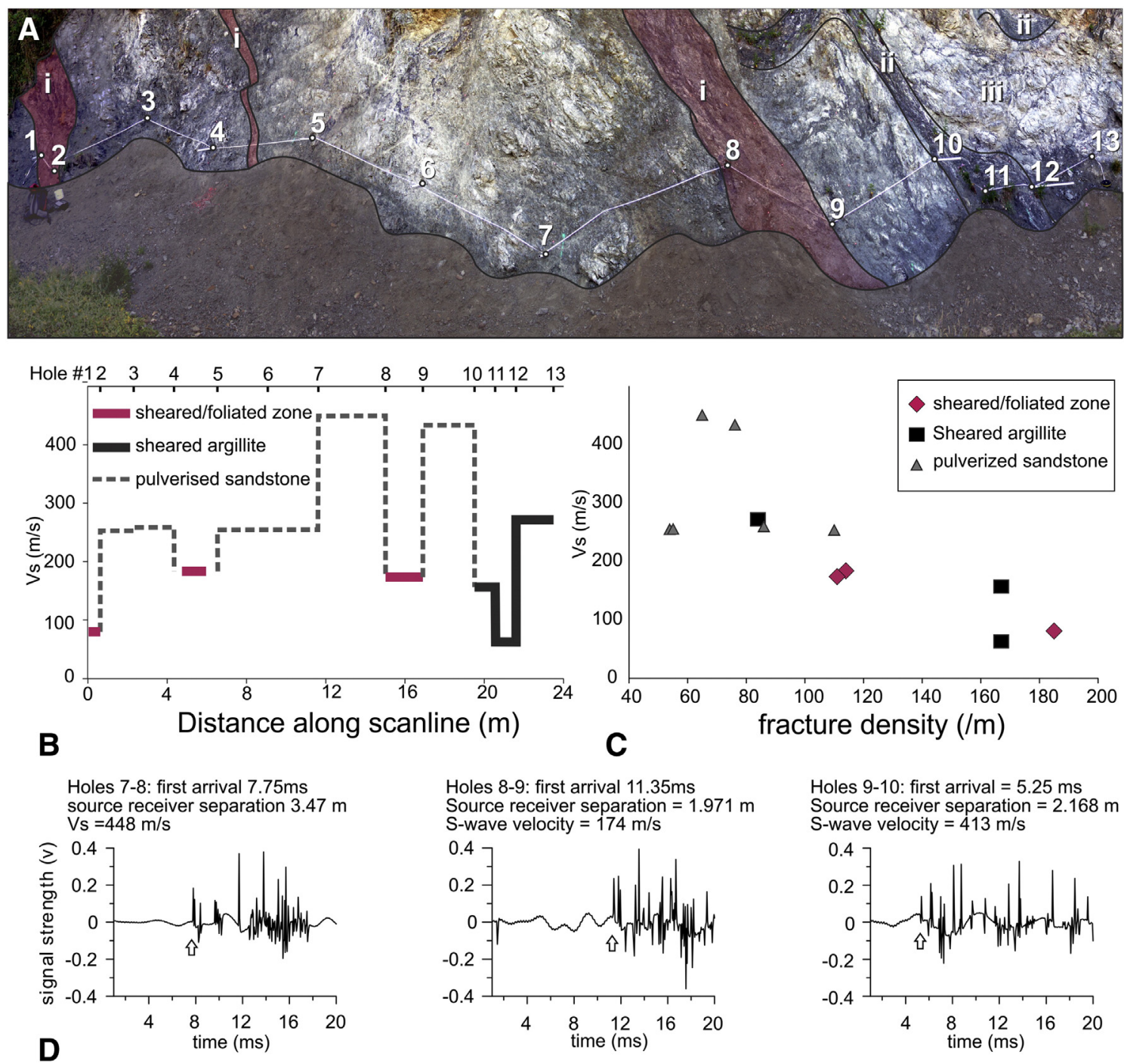

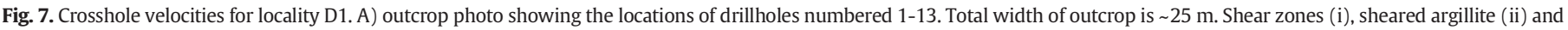

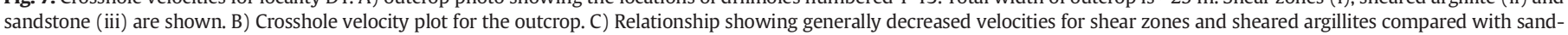
stones. D) examples of crosshole velocity seismograms. Arrows show first arrivals. 
Table 4

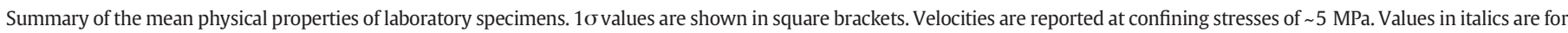
core, all other values are for irregular blocks tested using the point load technique.

\begin{tabular}{|c|c|c|c|c|c|c|}
\hline Sample suite & Dry Density (kg/m3) & Porosity (\%) & UCS (MPa) & Is50 (Mpa) & $\mathrm{Vp}(\mathrm{m} / \mathrm{s})$ & Vs $(\mathrm{m} / \mathrm{s})$ \\
\hline Intact & 2716 [9] & $0.27[0.14]$ & $\begin{array}{l}203-254(\text { tension }) \\
110 \text { (shear) }\end{array}$ & $7.37[0.75]$ & $4770[336]$ & $\begin{array}{l}2489[281] \\
2750\end{array}$ \\
\hline D2 (distal fault rocks) & $2634[248]$ & $3.58[0.61]$ & - & $2.07[1.11]$ & $2668[438]$ & $1744[531]$ \\
\hline D1 (pulverized fault rocks) & $2487[168]$ & $5.02[0.73]$ & - & $1.57[0.76]$ & 1499 [707] & $1080[507]$ \\
\hline
\end{tabular}

One core specimen from each orientation was fractured at regular intervals and shear wave velocities measured with increasing linear fracture density (Figure 8C). At a confining stress of $5 \mathrm{MPa}$, the shear wave velocity declined approximately linearly with increasing fracture density.
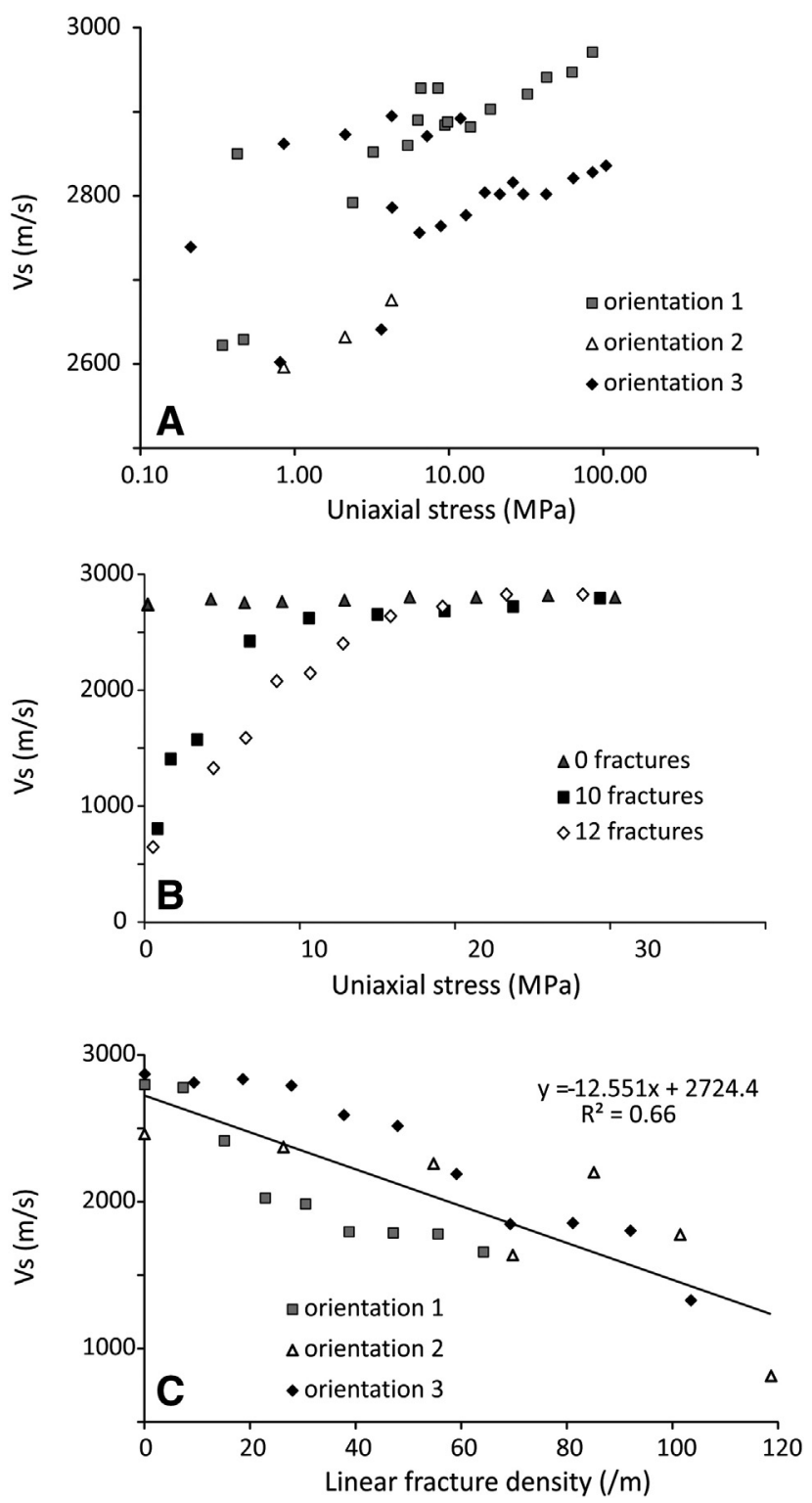

Fig. 8. Core testing results. A) Intact shear wave velocities for specimens cored from Torlesse greywacke river boulder sourced from the Hawkins River catchment at Dalethorpe. Note the expanded vertical scale compared with B. B) Ultrasonic shear wave velocity plotted as a function of uniaxial stress for an un-fractured specimen (triangles) and the same specimen with saw cut 'fractures'. The specimen was cored in orientation 3. C) Effects of Linear fracture density on shear wave velocity using results from all orientations of core.

\subsubsection{Tectonized rock}

Specimens from outcrop D2, located in the hanging wall of the fault, displayed a moderate reduction in density of $\sim 3 \%$ and a marked relative increase in porosity of $1100 \%$ compared with the intact specimens (Table 4). In comparison, specimens cut from a relatively intact block within the fault zone (block shown in Figure 4C) displayed a greater density reduction of $8 \%$ and a relative porosity increase of $1700 \%$ when compared with intact rock. The density of the fault zone specimen is consistent with values reported elsewhere for anything from slightly weathered (Raisbeck, 1973; Hicks, 2011) to moderately weathered (Hodder and Hetherington, 1991) and even highly weathered Torlesse greywacke (Martin, 1974).

The ultrasonic shear wave velocities of rectangular block specimens decline with increasing tectonization, and the range of velocities for specimens cut from a single sample becomes increasingly wide (Table 4). The average declining shear wave velocities exhibit a strong negative correlation with porosity and a positive correlation with point load strength when results are averaged for all specimens from a given sample (Figure 9A and B). Point load strength is negatively correlated with porosity (Figure 9C). Because intact specimen porosities of Torlesse greywacke are typically less than $0.5 \%$, any increase in porosity is predominantly caused by internal fracturing. Therefore, shear wave velocities and porosity may provide a useful indication of volumetric fracture intensity (Table 4).

\subsection{MASW shear wave velocity surveys and topographic profiles}

Perspective and cross-section views of the MASW shear wave velocity maps and topographic data are shown in Fig. 10. The inverted shear wave velocities range from $\sim 200$ to $\sim 1700 \mathrm{~m} / \mathrm{s}$. Beginning in the west, most of line 5 and the sub-parallel line 1 display low velocities compared with the other profiles. Velocities in the upper $5 \mathrm{~m}$ are as low as $\sim 200 \mathrm{~m} / \mathrm{s}$ on line $5.200 \mathrm{~m} / \mathrm{s}$ is at the upper limit of the range of velocities widely considered to represent liquefiable material (e.g. Lin et al., 2004; Özener, 2012). Such low velocities only occur in this part of the study area and are slightly higher below line 1 , where the ground surface is drier.

The $500 \mathrm{~m} / \mathrm{s}$ velocity boundary commonly represents the transition into completely weathered greywacke (Semmens et al., 2010; Hicks, 2011). This boundary extends deeper than $10 \mathrm{~m}$ along much of the central section of line 5 and the correlative parts of line 1 . This low velocity area correlates with a gravel-filled fault angle depression west of outcrop D1 (Figure 4d). No greywacke crops out for at least $150 \mathrm{~m}$ west of outcrop D1. Even below the fault angle gravel wedge, the shear wave velocity gradients west of D1 are considerably less steep than elsewhere in the survey area. This low velocity-gradient substrate occupies the same structural position as the Cretaceous outlier mapped just outside the field area (Speight, 1928) (cross section Figure 3). The velocity values and gradients are consistent with those mapped in Tertiary sandstones elsewhere in Canterbury (Duffy, 2008).

Velocities and velocity gradients increase sharply at the easternmost extent of line 5, and along line 4 . Higher velocities in the near surface correspond with the pulverized greywacke on the hanging wall of the Springfield fault, and the abrupt change corresponds to the overthrusting of footwall gravels at the western end of outcrop D1. At 

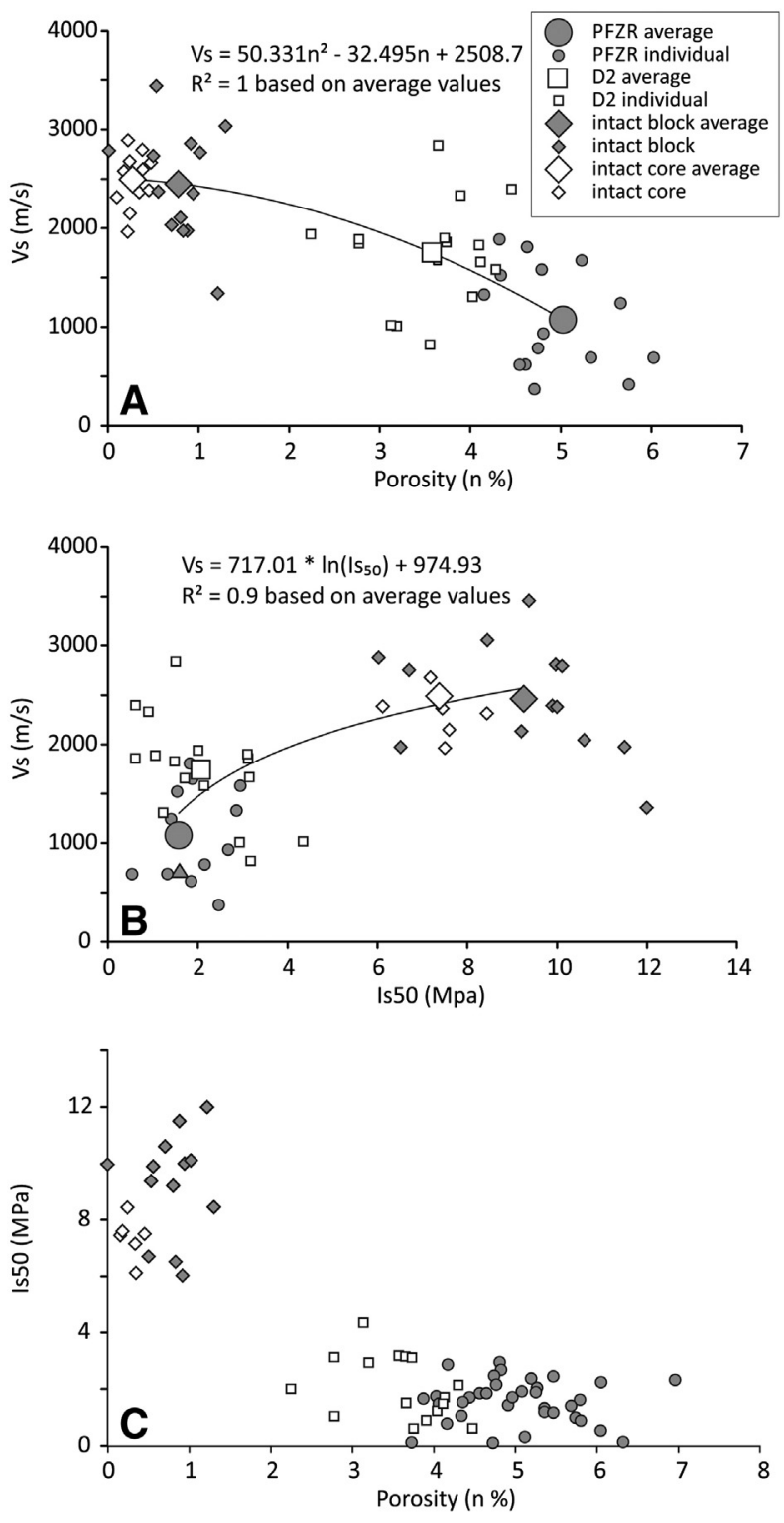

Fig. 9. Relationship between A) ultrasonic shear wave velocity and porosity, B) ultrasonic shear wave velocity and point load strength and C) Point load strength and porosity for specimens from intact boulders and tectonised outcrops of Torlesse greywacke.

depth, the high shear wave velocities extend further west than the projection of outcrop D1. This is consistent with previous GPR surveys that show deformation of the gravels west of D1, $>50 \mathrm{~m}$ into the footwall beyond the apparent main displacement plane of the fault (Figure 3). These results indicate that a greywacke duplex underlies the footwall gravels.

Above outcrop D1, the $500 \mathrm{~m} / \mathrm{s}$ boundary occurs at slightly less than $5 \mathrm{~m}$ depth, which agrees with the depth of the gravel above D1 (Figure 4A) and with GPR and resistivity surveys (Corboz et al., 2005). The near surface shear wave velocities at 5-10 m along line 4 are consistent with crosshole velocity measurements at outcrop D1, especially taking into account the effect of enhanced confinement of the MASW substrate compared with the face of outcrop D1. Further east, a 300$500 \mathrm{~m} / \mathrm{s}$ low velocity layer extends from the surface to depths of $5 \mathrm{~m}$ across much of lines 3 and 7 . These low velocities lie above the strath that we surveyed in the terrace edge (indicated on Figure 10) so may represent the depth extent of the greywacke gravels that form the terrace surface.

Shear wave velocities increase to $>500 \mathrm{~m} / \mathrm{s}$ below the elevation of the strath on lines 3 and 7 . However, the velocity map indicates extreme lateral and vertical velocity variability (Figure 10). The velocities on the western end of line 3 decline towards the NE-trending reach in the S. Hawkins River (dogleg in Figure 10), where the strath is displaced $\sim 2$ $m$ by a large landslide. The low-velocity western part of line 3 has similar velocity characteristics to the pulverised rocks above outcrop D1 (Figure 4). On line 7, the same velocity reduction occurs at the same distance from the fault trace and the terrace edge but further from the landslide. The velocity reduction may represent hanging-wall damage and weakening of the rock mass that contributed to the landslide. We note that this landslide must have occurred after the S. Hawkins River incised into terrace Ta, and did not involve activity of the main fault beneath the undisturbed surface of terrace Ta.

East of this low velocity damage zone, a distinctive finger of high velocity substrate marks the central part of both lines 3 and 7 (the high velocity zone - HVZ, Figure 10B). The HVZ displays elevated shear wave velocities and steep velocity gradients and coincides along strike with the flight of uplifted terraces north of the S. Hawkins River. The strath is warped upwards in this area and the shear wave velocities record the warping. The S. Hawkins River incises a deep gorge as it passes across the HVZ.

The eastern end of the HVZ corresponds with a marked reduction in the gradient of the S. Hawkins River, and with the eastern topographic scarps that bound the uplifted terraces north of the river. These scarps, previously interpreted as terrace edges (Speight, 1928; Evans, 2000), strike approximately parallel to the trace of the main, east-dipping thrust, and at a high angle to the direction of fluvial drainage through the Hawkins catchment. Furthermore, the eastern end of the HVZ is marked on both lines 3 and 7 by a deep low velocity zone that coincides with the base of the uplifted terraces. Based on the northeasterly strike of the terrace-bounding scarps, and on their discordance with fluvial patterns in the catchment, we suggest that the sharp lateral velocity boundary may represent a fault trace. We refer to this potential fault as the main downstream thrust (MDT - Figure 10) and interpret it as a backthrust off the MUT. On this basis, we interpret the low velocity zone east of the HVZ as a smaller damage zone associated with activity on the MDT. Preliminary air-photo interpretation is consistent with these interpretations, but trenching will be required to verify them. This indicates the potential for MASW to locate significant, unidentified faults.

East of the MDT damage zone, the shear wave velocity gradient is intermediate between that of the HVZ and the low gradients observed in the western part of lines 1 and 5 . Velocities in the upper $20 \mathrm{~m}$ range between 600 and $1200 \mathrm{~m} / \mathrm{s}$. This velocity gradient is consistent with the presence of highly weathered greywacke in the near surface grading quickly to moderately weathered greywacke at depth. This interpretation agrees with weathering observations at outcrops D3 and D4. It is also consistent with structure contour mapping of the unconformity below the Cretaceous/Tertiary cover sediments, which indicates that these outcrops lie just beneath the original unconformity (Evans, 2000).

In general, the shear wave velocities of lines 3 and 7 relate closely to the gradients of both branches of the Hawkins River. Steep gradients on the high velocity sections are separated from lower gradients on the lower velocity sections by distinct knick points.

\subsection{Integration of laboratory and field data}

We observed an apparent shear wave dispersion (frequency-dependent velocity) between laboratory and field scale experiments (Figure 11A) (e.g. Mukerji et al., 1995; Gettemy et al., 2004). We applied Suharsono et al.'s (2004) relationship to estimate RQD from this apparent dispersion, based on the relationship:

$\operatorname{RQD}(\%)=100^{(1-\delta)} \quad($ Suharsono et al., 2004)

where $\delta=\left[\frac{(V s \mu-V s \beta)^{2}}{(V s \mu+V s \beta)^{2}}\right]$, Vs $\mu$ is shear wave velocity of intact rock from ultrasonic testing, and Vs $\beta$ is the shear wave velocity inverted from surface wave velocity. 

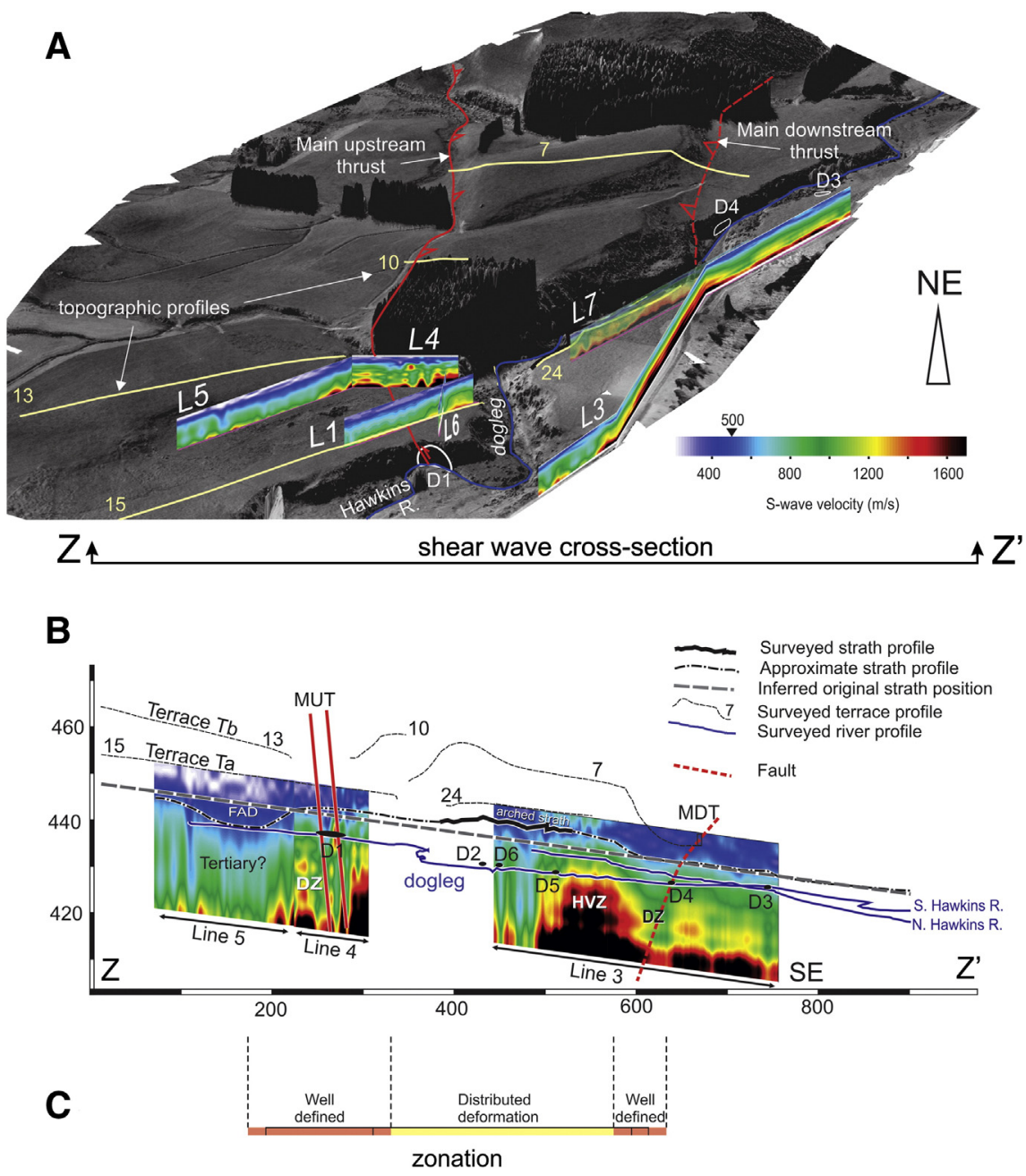

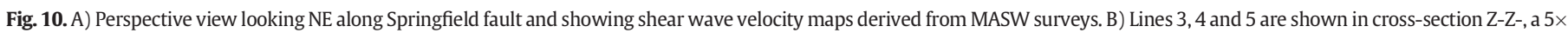

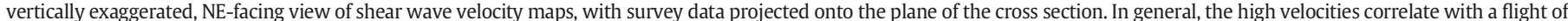

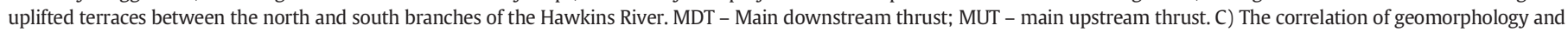
shear wave velocities leads to definition of well-defined and distributed fault avoidance zones for Terrace Ta, in accordance with Kerr et al. (2003).

We calculated RQD using Vs $\mu$ dervived from both site-selected and boulder core specimens (Vs $\mu_{(\text {boulder) }}$ and $V s \mu_{(\text {site })}$ respectively) and compared these results with scanline derived RQD (Table 5). The RQD calculated for outcrop D1 using site-material from the outcrop is low but still overestimated compared with the scanline fracture spacing. However, it may reflect the presence of rafts of relatively intact material within the fault zone that provided material for laboratory testing but were too high on the outcrop to be included on the scanline.

At outcrop D2, where the high velocity, least weathered material is exhumed, the RQD calculated using site material is approximately correct. At outcrop D3, the Vs $\mu_{\text {(site) }}$ was not measured but the observed $\mathrm{RQD}$ equates to a $\mathrm{Vs} \mu_{\text {(site) }}$ of $\sim 1100 \mathrm{~m} / \mathrm{s}$. This is consistent with the weathering of the outcrop.

The steep weathering gradients across the site are reflected in the relationship between fracture density and shear wave velocity. For instance, Fig. 11B integrates crosshole and MASW sonic shear wave velocity data with fracture densities observed at outcrop. The crosshole data from D1 together with the MASW velocities correlated with outcrops D3 and 4 lie outside the central HVZ. Data related to these relatively more weathered localities define a trend of decreasing shear wave velocity with increasing fracture density (Figure 11B). MASW velocities in the HVZ (outcrops D2, D5 and D7) do not adhere to the same trend but define a similar trend at higher velocity values. However, shear wave velocity increases approximately linearly with GSI (Figure 11C), which integrates the effects of fracturing and weathering. This indicates that weathering exerts a similarly major control on shear wave velocities compared with fracturing (e.g. Fumal, 1978; Hicks, 2011). GSI is applicable to flysch (Marinos and Hoek, 2001) and cataclastic rocks (Habimana et al., 2002) and therefore seems to provide a useful correlative classification against which field-survey shear wave velocities of greywacke substrate may be interpreted. This approach may feed directly into the geotechnical design via the modified Hoek Brown failure criterion of Habimana et al. (2002) and will be the subject of future research.

\section{Discussion}

In this study, we have examined both intact and tectonized greywackes, and characterized their shear wave velocities at laboratory and outcrop scale as a function of properties including porosity and fracture density. In common with previous studies (Zinszner et al., 2002; Gettemy et al., 2004; Rempe et al., 2013), the laboratory and outcrop studies both indicate the overwhelming influence of fracturing on shear wave velocities in greywacke. We have also described the variability in the fault zone rock material, rock mass characteristics, and shear wave velocity structure of the SFD. The results of these combined laboratory and field surveys support interpretation of velocity variations in the MASW surveys in terms of fracturing of the rock mass. The velocity gradient at depths $>5 \mathrm{~m}$ vary both vertically and laterally across the site. We note that the lateral resolution of the MASW 

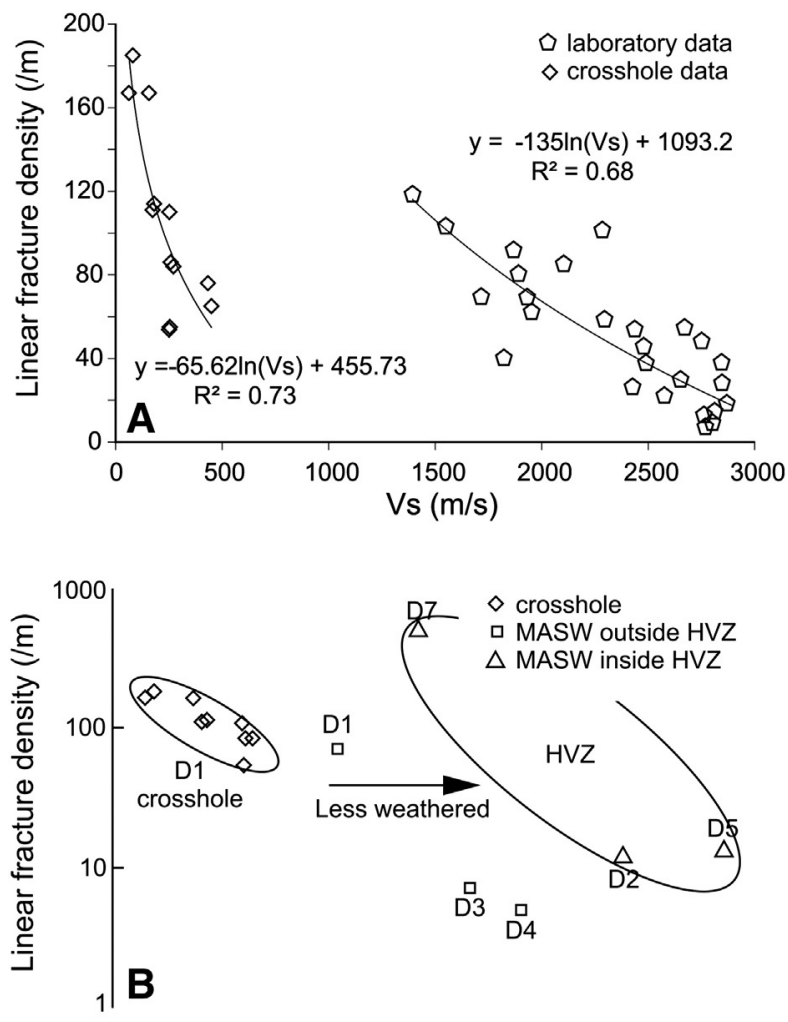

D3 문

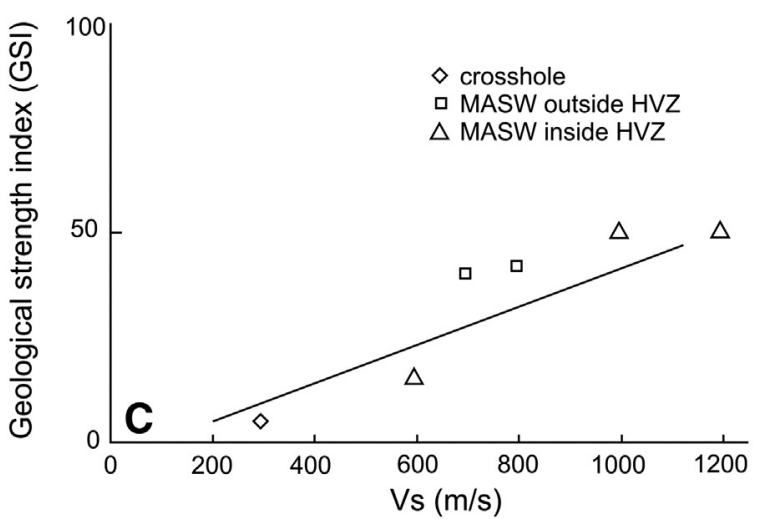

Fig. 11. A) Comparison of the relationships of sonic and ultrasonic velocity to linear fracture density. Both ultrasonic and sonic (outcrop) velocities decline with fracture density over the range tested. Ultrasonic and sonic velocity fields are widely separated. B) Integration of crosshole and MASW velocity data. The plot assumes that shear wave velocities can be approximately correlated with outcrops along strike. Note the generally high velocities obtained from MASW surveys in the area of uplift, compared with generally low velocities for similarly fractured rock elsewhere. C) A plot of GSI against shear wave velocity for the outcrops in B yields a strong, apparently linear correlation.

technique is limited by the width of the array, and that an array passing over a lateral contrast may lead to interpretation of lateral contrasts as vertical variation (e.g. Lin and Lin, 2007). Given an array dimension of $23 \mathrm{~m}$ and a near offset of $10 \mathrm{~m}$, steep lateral velocity gradients as interpreted here are probably only laterally resolved within $\pm 20 \mathrm{~m}$.

Table 5

Calculated RQD values using Vsu measured from boulder core (boulder) and site selected 'intact' rock (site). The Vs $\mu_{\text {(site) }}$ for D3 was not measured. The value shown in square brackets is that which would be consistent with the observed RQD.

\begin{tabular}{lllllll}
\hline Locality & $\mathrm{Vs} \mu_{\text {(boulder) }}$ & $\mathrm{Vs} \mu_{(\text {site) }}$ & $\mathrm{Vs} \beta$ & $\mathrm{RQD}_{(\text {site) }}$ & $\mathrm{RQD}$ (boulder) & $\mathrm{RQD}_{\text {(observed) }}$ \\
\hline D1 & 2750 & 1080 & 300 & 23 & 5 & $<5$ \\
$\mathrm{D} 2$ & 2750 & 1744 & 1000 & 71 & 36 & 77 \\
$\mathrm{D} 3$ & 2750 & {$[1100]$} & 700 & - & 19 & 79
\end{tabular}

The velocity zones we have mapped are much wider than this and are consistent with outcrop and other indicators. For instance, the steep lateral velocity gradients along survey lines 4 and 5 clearly image the exhumation of greywacke and the presence of a fault angle depression, both of which are confirmed by outcrop. GPR has indicated that the gravels below lines 1, 4 and 5 is displaced by at least three shears that displace buried gravels by $0.4 \mathrm{~m}$ each (Corboz et al., 2005). One of these is located several 10's of meters west of outcrop D1. Although the displacement of the gravels is not clear on topographic profiles (despite the presence of a swamp) or on the shear wave profiles, the MASW survey clearly indicates the exhumation of bedrock forward of outcrop D1, which implies that discrete deformation is occurring there and is consistent with the GPR survey. The shear wave velocities on line 3 agree with surveying of the strath topography, which indicates that the strath is warped (Figure 10).

These surveys provide useful data on earthquake timing. The presence of shear zones in the footwall gravels despite the absence of surface displacements, and the deformation of the hanging wall strath without warping of the terrace surface, both imply that the last rupture event took place while the river bed was at the level of Terrace Ta. This provides a clear example of a common situation, where an active fault across a river flood plain can leave neither obvious evidence of recent activity, nor any indication of the extent of distributed faulting and deformation. In this situation, and despite an apparently obvious single constrained fault scarp that increases in elevation with terrace age, the MASW survey clearly shows that the true extent of deformation on multiple faults extends over several hundred meters.

Both observational and MASW data indicate that the deformation causes extensive damage accumulation and related failure in the hanging wall of the SFD. We infer a similar but narrower damage zone for the proposed backthrust. These damage zones are consistent with studies that show that ground-motion intensity is greater on the hanging wall of dip-slip faults, and that vertical ground motions dominate on the hanging wall (Abrahamson and Somerville, 1996; Oglesby et al., 1998, 2000; Duan and Oglesby, 2005). Concentration of vertical motion in the hanging wall causes dynamic fluctuations in the normal stress, contributing to rock mass dilation and hanging wall damage. The $100 \mathrm{~m}$ wide fault core damage zone seen over the main fault trace in the MASW survey is of a similar width to the $80 \mathrm{~m}$ wide zone of surface cracking mapped along the Chelungpu fault by Kelson et al. (2001). Significantly, the MASW and topographic data both indicate that secondary faulting and deformation extend beyond both sides of the fault core over at least $800 \mathrm{~m}$.

\subsection{Application to land use planning}

This study has shown that the shear wave velocity structure of buried bedrock correlates strongly with along strike geomorphic indicators and independent geophysical documentation of fault complexity and deformation. The New Zealand Minstry for the Environment (MfE) guidelines for development of land adjacent to active faults (Kerr et al., 2003) requires planners to quantify the hazard posed by earthquake ground rupture using information including fault location and deformation extent. In this regard, planners must demarcate a fault avoidance zone that provides a buffer either side of the known fault trace. This fault avoidance zone must account for fault complexity, which amounts to a measure of the width and style of the zone of deformation either side of the fault trace (e.g. Villamor et al., 2012).

Consent for building within fault avoidance zones is based on a matrix of the documented fault complexity, building significance and surface rupture recurrence interval. In most instances, the building activity matrix treats zones of uncertain fault complexity as zones of distributed deformation. This means that robust reclassification of the fault as distributed or well defined offers a planning advantage by reducing either or both of the size of the fault avoidance zone and the extent of restricted building activity within the zone. 
The correlations shown here, between geomorphology and shear wave velocity, suggest that MASW surveys may provide a costeffective means of acquiring the accurate fault information that is required in order to best implement the MfE guidelines. This is especially true in instances where the fault zone is poorly exposed and/or buried under meters of alluvium.

For instance, based on our survey we can classify the lower terraces in terms of well-defined and distributed deformation, and create appropriate fault avoidance zones. On terrace Ta north of the S. Hawkins River, the contrast between fault angle depression gravels and relatively highvelocity greywacke shows that the zone of well-defined deformation zone is likely to extend at least as far west as the easternmost part of line 5 (Figure 10). This is consistent with radar surveys of deformation in the gravels well to the west of outcrop D1 (Corboz et al., 2005). On the south side of the river, the low velocities at the west ends of lines 3 and 7 suggest that the terrace edge may be unstable. Further east, we can identify a distributed deformation zone that correlates with the uplifted terrace north of the river. Our MASW survey and airphoto analysis suggest that a secondary zone of well-defined deformation is present east of the HVZ and should be further investigated. This zonation represents a significant improvement on the uncertain classification that would have been applied to the lowest terraces prior to these surveys. In addition to zonation improvements, the identification of the low velocity material is useful design information for engineers designing earthquake code-compliant buildings such as typical NZ wood framed houses, which are permitted within the fault avoidance zone of faults such as this that have a long recurrence interval.

\section{Conclusions}

This study has demonstrated the efficacy of MASW surveys for mapping of surface deformation adjacent to active faults. The shear wave velocities clearly define fault zones developed within otherwise-strong greywacke, due to cataclastically-enhanced weathering and increased fracturing. Zones of distributed deformation are also defined. On this basis, it seems that MASW surveying as part of the planning process should provide insight into past and future distribution of deformation on a buried fault zone. These type of results provide a clear planning advantage in tectonically and fluvially active rangefront settings.

\section{Acknowledgements}

We thank Gary and Tom Ferguson for access to the study site. This research was funded by an Earthquake Commission non-biennial research grant 07/U537 to BD. We thank Dr. Carlos Carranza-Torres for editorial handling and three anonymous reviewers whose thoughtful and thorough reviews have contributed greatly to improving the manuscript.

\section{References}

Abrahamson, N.A., Somerville, P.G., 1996. Effects of the hanging wall and footwall on ground motions recorded during the Northridge earthquake. Bull. Seismol. Soc. Am. 86, S93-S99.

Anderson, J.G., Lee, Y., Zeng, Y., Day, S., 1996. Control of strong motion by the upper 30 meters. Bull. Seismol. Soc. Am. 86, 1749-1759.

Andrews, P.B., Speden, I.G., Bradshaw, J.D., 1976. Lithological and paleontological content of the Carboniferous-Jurassic Canterbury Suite, South Island, New Zealand. N. Z. J. Geol. Geophys. 19, 791-819.

Andrus, R.D., Stokoe, K.H., 2000. Liquefaction resistance of soils from shear-wave velocity. J. Geotech. Geoenviron. 126, 1015-1025.

Becker, J., Saunders, W., Van Dissen, R.,2005. Planning for the development of land on or close to active faults: A study of the adoption and use of the Active Fault Guidelines. Institute of Geological \& Nuclear Sciences Limited.

Benites, R., Olsen, K.B., 2005. Modeling strong ground motion in the Wellington Metropolitan Area, New Zealand. Bull. Seismol. Soc. Am. 95, 2180-2196. http://dx.doi.org/10. $1785 / 0120040223$.

Borcherdt, R.D., Glassmoyer, G., 1992. On the characteristics of local geology and their influence on ground motions generated by the Loma Prieta earthquake in the San Francisco Bay region, California. Bull. Seismol. Soc. Am. 82, 603-641.
Buech, F., Davies, T.R., Pettinga, J.R., 2010. The Little Red Hill seismic experimental study: topographic effects on ground motion at a bedrock-dominated mountain edifice. Bull. Seismol. Soc. Am. 100, 2219-2229. http://dx.doi.org/10.1785/0120090345.

Burjánek, J., Moore, J.R., Yugsi Molina, F.X., Fäh, D., 2012. Instrumental evidence of normal mode rock slope vibration. Geophys. J. Int. 188, 559-569. http://dx.doi.org/10.1111/j. 1365-246X.2011.05272.x.

Campbell, J., Pettinga, J., Jongens, R., 2012. The tectonic and structural setting of the 4th September 2010 Darfield (Canterbury) Earthquake sequence, New Zealand. N. Z. J. Geol. Geophys. 55, 155-168 (Canterbury, New Zealand, 2010-2011 earthquake sequence).

Corboz, P., Horstmeyer, H., Tronicke, J., Nobes, D., Campbell, J., Green, A.G., 2005. Highresolution geophysical surveying at the Springfield fault, New Zealand. Meeting of the Environmental and Engineering Geophysical Society, European Section, 11, 0 -Abstract 809.

Cowan, H.A., Nicol, A., Tonkin, P.L., 1996. A comparison of historical and paleoseismicity in a newly formed fault zone and a mature fault zone, north Canterbury, New Zealand. J. Geophys. Res. 101, 6021-6036.

Cox, S.C., Barrell, D.J.A., 2007. Geology of the Aoraki area. Institute of Geological and Nuclear Sciences Geological Map 15.

DeMets, C., Gordon, R.G., Argus, D.F., 2010. Geologically current plate motions. Geophys. J Int. $181,1-80$.

Dobry, R., Borcherdt, R.D., Crouse, C.B., Idriss, I.M., Joyner, W.B., Martin, G.R., Power, M.S. Rinne, E.E., Seed, R.B., 2000. New site coefficients and site classification system used in recent building seismic code provisions. Earthquake Spectra 16, 41-67.

Dor, O., Ben-Zion, Y., Rockwell, T., Brune, J., 2006a. Pulverized rocks in the Mojave section of the San Andreas Fault Zone. Earth Planet. Sci. Lett. 245, 642-654. http://dx.doi.org 10.1016/j.epsl.2006.03.034.

Dor, O., Rockwell, T.K., Ben-Zion, Y., 2006b. Geological observations of damage asymmetry in the structure of the San Jacinto, San Andreas and Punchbowl faults in Southern California: A possible indicator for preferred rupture propagation direction. Pure Appl. Geophys. 163, 301-349.

Dorn, C., Green, A.G., Jongens, R., Carpentier, S., Kaiser, A.E., Campbell, F., Horstmeyer, H. Campbell, J., Finnemore, M., Pettinga, J., 2010. High-resolution seismic images of potentially seismogenic structures beneath the northwest Canterbury Plains, New Zealand. J. Geophys. Res. Solid Earth 115. http://dx.doi.org/10.1029/2010JB007459.

Duan, B., Oglesby, D.D., 2005. The dynamics of thrust and normal faults over multiple earthquake cycles: Effects of dipping fault geometry. Bull. Seismol. Soc. Am. 95, 1623-1636.

Duffy, B.G., 2008. Development of Multi-Channel Analysis of Surface Waves (MASW) for characterising the internal structure of active fault zones as a predictive method of identifying the distribution of ground deformation. Geology MSc, University of Canterbury.

Duffy, B., Quigley, M.C., Barrell, D., Van Dissen, R., Stahl, T. Leprince, S., McInnes, C. Bilderback, E., 2013. Fault kinematics and surface deformation across a releasing bend during the $2010 \mathrm{M}_{\mathrm{W}}$ 7.1 Darfield, New Zealand, earthquake revealed by differential LiDAR and cadastral surveying. GSA Bull. 125, 420-431. http://dx.doi.org/10. 1130/B30753.1.

Evans, S.T., 2000. Paleoseismic analysis of the Springfield Fault, Central Canterbury. BSc (Hons), University of Canterbury.

Forsyth, P.J., Barrell, D.J.A., Jongens, R., 2008. Geology of the Christchurch area. Institute of Geological and Nuclear Sciences Geological Map 16, (1 sheet +67 pp.).

Fumal, T.E., 1978. Correlations between seismic wave velocities and physical properties of near-surface geologic materials in the southern San Francisco Bay region, California. U.S. Geol. Surv. Report Open-File Rept. 78-1067.

Gettemy, G.L., Tobin, H.J., Hole, J.A., Sayed, A.Y., 2004. Multi-scale compressional wave velocity structure of the San Gregorio Fault zone. Geophys. Res. Lett. 31.

Ghisetti, F.C., Sibson, R.H., 2012. Compressional reactivation of E-W inherited normal faults in the area of the 2010-2011 Canterbury earthquake sequence. N. Z. J. Geol. Geophys. 55, 177-184 (Special issue: Canterbury, New Zealand, 2010-2011 earthquake sequence).

Habimana, J., Labiouse, V., Descoeudres, F., 2002. Geomechanical characterisation of cataclastic rocks: Experience from the Cleuson-Dixence project. Int. J. Rock Mech. Min. Sci. 39, 677-693.

Hart, E.W., Bryant, W.A., 1997. Fault rupture hazard zones in California: Alquist-Priolo earthquake fault zoning Act with index to earthquake fault zones maps. Californian Department of Conservation, Division of Mines and Geology, p. 47.

Hicks, M.A., 2011. Geotechnical investigations of wind turbine foundations using multichannel analysis of surface waves (MASW). Geology MSc, University of Canterbury.

Hodder, A.P.W., Hetherington, J.R., 1991. A quantitative study of the weathering of greywacke. Eng. Geol. 31, 353-368. http://dx.doi.org/10.1016/0013-7952(1)90017-F.

Hoek, E., Marinos, P., Benissi, M., 1998. Applicability of the geological strength index (GSI) classification for very weak and sheared rock masses. The case of the Athens Schist Formation. Bull. Eng. Geol. Environ. 57, 151-160.

Hough, S.E., Altidor, J.R., Anglade, D., Given, D., Janvier, M.G., Maharrey, J.Z., Meremonte M., Mildor, B.S.-L., Prepetit, C., Yong, A., 2010. Localized damage caused by topographic amplification during the 2010 M 7.0 Haiti earthquake. Nat. Geosci. 3, 778-782. http://dx.doi.org/10.1038/ngeo988.

ISRM, 1979. Suggested methods for determining the uniaxial compressive strength and deformability of rock materials. Int. J. Rock Mech. Min. Sci. 16, 135-140.

ISRM, 1985. Suggested method for determining point load strength. Int. J. Rock Mech. Min. Sci. 22, 53-60.

Ivanov, J., Park, C.B., Miller, R.D., Xia, J., 2005. Analyzing and filtering surface-wave energy by muting shot gathers. J. Environ. Eng. Geophys. 10, 307-322.

Ivanov, J., Miller, R.D., Lacombe, P., Johnson, C.D., Lane Jr., J.W., 2006. Delineating a shallow fault zone and dipping bed rock strata using multichannal analysis of surface waves with a land streamer. Geophysics 71. 
Jongens, R., Barrell, D.J.A., Campbell, J.K., Pettinga, J.R., 2012. Faulting and folding beneath the Canterbury Plains identified prior to the 2010 emergence of the Greendale Fault. N. Z. J. Geol. Geophys. 55, 169-176 (Special issue: Canterbury, New Zealand, 20102011 earthquake sequence).

Kelson, K.I., Kang, K.H., Page, W.D., Lee, C.T., Cluff, L.S., 2001. Representative styles of deformation along the Chelungpu fault from the 1999 Chi-Chi (Taiwan) earthquake: Geomorphic characteristics and responses of man-made structures. Bull. Seismol. Soc. Am. 91, 930-952.

Kerr, J., Nathan, S., Van Dissen, R., Webb, P., Brunsdon, D., King, A., 2003. Planning for development of land on or close to active faults: A guideline to assist resource management planners in New Zealand. Ministry for the Environment.

King, G., Nábělek, J., 1985. Role of fault bends in the initiation and termination of earthquake rupture. Science 228, 984-987.

King, G.C.P., Vita-finzi, C., 1981. Active folding in the Algerian earthquake of 10 October 1980. Nature 292, 22-26.

Lee, Y.H., Chen, H.S., Rau, R.J., Chen, C.L., Hung, P.S., 2006. Revealing surface deformation of the 1999 Chi-Chi earthquake using high-density cadastral control points in the Taichung area, central Taiwan. Bull. Seismol. Soc. Am. 96, 2431-2440. http://dx.doi. org $/ 10.1785 / 0120060055$.

Lee, Y.H., Wu, K.C., Rau, R.J., Chen, H.C., Lo, W., Cheng, K.C., 2010. Revealing coseismic displacements and the deformation zones of the 1999 Chi-Chi earthquake in the Tsaotung area, central Taiwan, using digital cadastral data. J. Geophys. Res. Solid Earth 115, B03419. http://dx.doi.org/10.1029/2009jb006397 (13 pp.).

Lee, Y.H., Chen, Y.C., Chen, C.L., Rau, R.J., Chen, H.C., Lo, W., Cheng, K.C., 2011. Revealing coseismic displacement and displacement partitioning at the northern end of the 1999 Chi-Chi earthquake, central Taiwan, using digital cadastral data. Bull. Seismol. Soc. Am. 101, 1199-1212. http://dx.doi.org/10.1785/0120100156.

Lin, C.-P., Lin, C.-H., 2007. Effect of lateral heterogeneity on surface wave testing: Numerical simulations and a countermeasure. Soil Dyn. Earthq. Eng. 27, 541-552.

Lin, C.P., Chang, C.C., Chang, T.S., 2004. The use of MASW method in the assessment of soil liquefaction potential. Soil Dyn. Earthq. Eng. 24, 689-698.

Little, T.A., Jones, A., 1998. Seven million years of strike-slip and related off-fault deformation, northeastern Marlborough fault system, South Island, New Zealand. Tectonics 17, 285-302. http://dx.doi.org/10.1029/97tc03148.

Luo, Y., Xia, J., Liu, J., Xu, Y., Liu, Q., 2009. Research on the middle-of-receiver-spread assumption of the MASW method. Soil Dyn. Earthq. Eng. 29, 71-79. http://dx.doi. org/10.1016/j.soildyn.2008.01.009.

Marinos, P., Hoek, E., 2001. Estimating the geotechnical properties of heterogeneous rock masses such as flysch. Bull. Eng. Geol. Environ. 60, 82-92.

Martin, G.R., Miller, P.J., 1974. Joint strength characteristics of a weathered rock. 3rd International Congress on Rock Mechanics. ISRM, Denver.

Miller, R.D., Xia, J., Park, C.B., Ivanov, J.M., 1999. Multichannel analysis of surface waves to map bedrock. Lead. Edge (Tulsa, OK) 18, 1392-1396.

Mukerji, T., Mavko, G., Mujica, D., Lucet, N., 1995. Scale-dependent seismic velocity in heterogeneous media. Geophysics 60, 1222-1233.

Norris, R.J., Cooper, A.F., 2001. Late Quaternary slip rates and slip partitioning on the Alpine fault, New Zealand. J. Struct. Geol. 23, 507-520.

Oglesby, D.D., Archuleta, R.J., Nielsen, S.B., 1998. Earthquakes on dipping faults: The effects of broken symmetry. Science 280, 1055-1059.

Oglesby, D.D., Archuleta, R.J., Nielsen, S.B., 2000. The three-dimensional dynamics of dipping faults. Bull. Seismol. Soc. Am. 90, 616-628. http://dx.doi.org/10.1785/ 0119990113.

Okaya, D., Christensen, N., Stanley, D., Stern, T., 1995. Crustal anisotropy in the vicinity of the Alpine Fault Zone, South Island, New Zealand. N. Z. J. Geol. Geophys. 38, 579-583.

Özener, P., 2012. Estimation of residual shear strength ratios of liquefied soil deposits from shear wave velocity. Earthq. Eng. Eng. Vib. 11, 461-484. http://dx.doi.org/10 1007/s11803-012-0134-0.

Panzera, F., Pischiutta, M., Lombardo, G., Monaco, C., Rovelli, A., 2014. Wavefield polarization in fault zones of the western flank of Mt. Etna: Observations and fracture orientation modelling. Pure Appl. Geophys. 1-15 http://dx.doi.org/10.1007/s00024014-0831-X

Park, C.B., Miller, R.D., Xia, J., 1998. Imaging dispersion curves of surface waves on multichannel record. 68th Annual International Meeting of the Society of Exploration Geophysicists, Expanded Abstracts, pp. 1377-1380.

Park, C.B., Miller, R.D., Xia, J., 1999. Multichannel analysis of surface waves. Geophysics 64 800-808.

Pettinga, J.R., Yetton, M.D., Van Dissen, R.J., Downes, G., 2001. Earthquake source identification and characterisation for the Canterbury Region, South Island, New Zealand. Bull. N. Z. Soc. Earthq. Eng. 34, 282-317.

Philip, H., Meghraoui, M., 1983. Structural analysis and interpretation of the surface deformations of the El Asnam earthquake of October 10, 1980 (Mediterranean area). Tectonics 2, 17-49.

Pischiutta, M., Salvini, F., Fletcher, J., Rovelli, A., Ben-Zion, Y., 2012. Horizontal polarization of ground motion in the Hayward fault zone at Fremont, California: dominant faulthigh-angle polarization and fault-induced cracks. Geophys. J. Int. 188, 1255-1272. http://dx.doi.org/10.1111/j.1365-246X.2011.05319.x.

Quigley, M.C., Van Dissen, R., Villamor, P., Litchfield, N., Barrell, D., Furlong, K., Stahl, T., Duffy, B., Bilderback, E., Noble, D., Townsend, D., Begg, J., Jongens, R., Ries, W.
Claridge, J., Klahn, A., Mackenzie, H., Smith, A., Hornblow, S., Nicol, R., Cox, S., Langridge, R., Pedley, K., 2010. Surface rupture of the Greendale Fault during the Darfield (Canterbury) earthquake, New Zealand: Initial findings. Bull. N. Z. Soc. Earthq. Eng. 43, 236-242.

Quigley, M.C., Van Dissen, R., Litchfield, N., Villamor, P., Duffy, B., Barrell, D., Furlong, K. Stahl, T., Bilderback, E., Noble, D., 2012. Surface rupture during the $2010 \mathrm{M}_{\mathrm{W}} 7.1$ Darfield (Canterbury) earthquake: implications for fault rupture dynamics and seismic-hazard analysis. Geology 40, 55-58. http://dx.doi.org/10.1130/G32528.1.

Raisbeck, D., 1973. Strength parameters for weathered sandstone. N. Z. Eng. 28, 254-260.

Read, S.A.L., Richards, L.R., Perrin, N.D., 1999. Applicability of the Hoek-Brownfailure criterion to New Zealand greywacke rocks. 9th International Society for Rock Mechanics Congress. ISRM, Paris, pp. 655-660.

Rempe, M., Mitchell, T., Renner, J., Nippress, S., Ben-Zion, Y., Rockwell, T., 2013. Damage and seismic velocity structure of pulverized rocks near the San Andreas Fault. J. Geophys. Res. Solid Earth 118, 1-19. http://dx.doi.org/10.1002/jgrb.50184.

Richards, L.R., Read, S.A.L., Perrin, N.D., 2001. Comparison of the Hoek-Brown failure criterion with laboratory and field test results for closely-jointed New Zealand greywacke rocks. In: Särkkä, P., Eloranta, P. (Eds.), Rock Mechanics - a Challenge for Society: Proceedings of the ISRM Regional Symposium EUROCK 2001, Espoo, Finland, 4-7 June 2001. International Society for Rock Mechanics, Lisse, The Netherlands, pp. 283-288.

Ruegg, J.C., Kasser, M., Tarantola, A., Lepine, J.C., Chouikrat, B., 1982. Deformations associated with the El Asnam earthquake of 10 October 1980: Geodetic determination of vertical and horizontal movements. Bull. Seismol. Soc. Am. 72, 2227-2244.

Semmens, S., Dellow, G.D., Perrin, N.D., 2010. It's Our Fault - geological and geotechnical characterization of the Wellington Central Business District. GNS Science Consultancy Report 2010/176, p. 52.

Similox-Tohon, D., Sintubin, M., Muchez, P., Verhaert, G., Vanneste, K., Fernandez, M., Vandycke, S., Vanhaverbeke, $\mathrm{H}$., Waelkens, M., 2006. The identification of an active fault by a multidisciplinary study at the archaeological site of Sagalassos (SW Turkey). Tectonophysics 420, 371-387.

Speight, R., 1928. The geology of the Malvern Hills. New Zealand Department of Scientific and Industrial Research Geological Memoirs 1, p. 72

Stahl, T., Winkler, S., Bebbington, M.S., Quigley, M.C., Duffy, B., Duke, D., 2013. Schmidt hammer dating of late Quaternary fluvial terraces in New Zealand. Earth Surf. Process. Landf. http://dx.doi.org/10.1002/esp.3427.

Steacy, S., Jiménez, A., Holden, C., 2014. Stress triggering and the Canterbury earthquake sequence. Geophys. J. Int. 196, 473-480. http://dx.doi.org/10.1093/gji/ggt380.

Stokoe, K.H., Wright, S.G., Bay, J.A., Roesset, J.M., 15-25, 1994. Characterization of geotechnical sites by SASW method. Geophysical characterization of sites, pp. 15-25.

Suharsono, Samsudin, A.R., Rafek, A.G., 2004. Computation of rock quality designation (RQD) using the spectral analysis surface wave method. Bull. Geol. Soc. Malaysia 49, 51-55.

Turk, N., Dearman, W.R., 1986. Correction Equation on the influence of length to diameter ratio on the uniaxial compressive strength of rocks. Eng. Geol. 22, 293-300.

Van Dissen, R., Barrell, D., Litchfield, N., King, A., Quigley, M.C., Villamor, P., Furlong, K., Mackenzie, H., Klahn, A., Begg, J., Townsend, D., Stahl, T., Noble, D., Duffy, B., Bilderback, E., Jongens, R., Cox, S., Langridge, R., Ries, W., Dhakal, R., Smith, A., Nicol, R., Pedley, K., Henham, H., Hunter, R., 2011. Surface rupture displacement on the Greendale Fault during the Mw 7.1 Darfield (Canterbury) Earthquake, New Zealand, and its impact on man-made structures. Ninth Pacific conference on earthquake engineering, building an earthquake-resilient society, paper 186 . New Zealand Society for Earthquake Engineering, Auckland, New Zealand (8 pp.).

Villamor, P., Litchfield, N., Barrell, D., Van Dissen, R., Hornblow, S., Quigley, M.C., Levick, S., Ries, W., Duffy, B., Begg, J., Townsend, D., Stahl, T., Bilderback, E., Noble, D., Furlong, K., Grant, H., 2012. Map of the 2010 Greendale Fault surface rupture, Canterbury, New Zealand: Application to land use planning New Zealand. J. Geol. Geophys. 55, 223-330 (Special issue: Canterbury, New Zealand, 2010-2011 earthquake sequence).

Wulff, A.M., Raab, S., Huenges, E., 2000. Alteration of seismic wave properties and fluid permeability in sandstones due to microfracturing. Phys. Chem. Earth Solid Earth Geod. 25, 141-147.

Xia, J., Miller, R.D., Park, C.B., 1999. Estimation of near-surface shear-wave velocity by inversion of Rayleigh waves. Geophysics 64, 691-700.

Yielding, G., Jackson, J.A., King, G.C.P., Sinvhal, H., Vita-Finzi, C., Wood, R.M., 1981. Relations between surface deformation, fault geometry, seismicity, and rupture characteristics during the El Asnam (Algeria) earthquake of 10 October 1980. Earth Planet. Sci. Lett. 56, 287-304.

Yunmin, C., Han, K., Ren-Peng, C., 2005. Correlation of shear wave velocity with liquefaction resistance based on laboratory tests. Soil Dyn. Earthq. Eng. 25, 461-469.

Zhang, L., 2010. A simple method for evaluating liquefaction potential from shear wave velocity. Front. Archit. Civ. Eng. China 4, 178-195. http://dx.doi.org/10.1007/ s11709-010-0023-4.

Zinszner, B., Meynier, P., Cabrera, J., Volant, P., 2002. Ultrasonic, sonic and seismic waves velocity in shale from Tournemire tunnel. Impact of anisotropy and natural fractures. Oil Gas Technol. 57, 341-353. 